\title{
Strategies for overcoming ABC-transporters-mediated multidrug resistance (MDR) of tumor cells ${ }^{\star}$
}

\author{
Edward Borowski ${ }^{\star}$, Maria M. Bontemps-Gracz ${ }^{\star}$ and Agnieszka Piwkowska \\ Department of Pharmaceutical Technology and Biochemistry, Gdańsk University of Technology, Gdańsk, Poland;

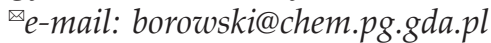

Received: 24 May, 2005; revised: 23 June, 2005; accepted: 29 July, 2005

available on-line: 15 September, 2005

\begin{abstract}
The development of multidrug resistance (MDR) of tumors is a major cause of failure in antitumor chemotherapy. This type of crossresistance is due to the expression of $A B C$ transporter glycoproteins actively effluxing the drug from the cells against the concentration gradient at the expense of metabolic energy, thus preventing the accumulation in cells of therapeutic concentration of active agents. In this review strategies for overcoming this adverse phenomenon are discussed. They comprise the control of expression of MDR glycoprotein transporters and control of the functioning of the expressed transporter proteins. The latter approach is discussed in more detail, comprising the following general strategies: (i) development of compounds that are not substrates of efflux pump(s), (ii) use of agents that inactivate (inhibit) MDR proteins, (iii) design of cytostatics characterized by fast cellular uptake, surpassing their mediated efflux, (iv) use of compounds competing with the drug for the MDR protein-mediated efflux. Positive and negative aspects of these strategies are analysed, with special attention put on strategy based on the use of MDR modulators in combination therapy, allowing the restoration of cytotoxic activity of clinical cytostatics towards resistant tumor cells.
\end{abstract}

Keywords: multidrug resistance, antitumor cytostatics, antimetabolites, modulators

Chemotherapy belongs to the most potent tools in contemporary medicine, enabling successful treatment of numerous microbial infections as well as neoplastic diseases. While the "chemotherapy era" has already brought solutions to many clinical problems, its potential is still not fully exploited and the development of new drugs, more effective and with better selectivity, is badly needed. Unfortunately, the brilliant achievements of chemotherapy have been endangered by the development of mutational or phenotypic resistance of pathogenic organisms towards applied chemotherapeutical agents, making them useless. This unfortunate phenomenon concerns all pathogens submitted to chemotherapeutical treatment, including neoplastic cells. In this review we will concentrate on the problems of resistance to anticancer drugs.
During the past five decades the development and use of anticancer agents has become one of the most important ways of controlling malignant diseases. Their action ends up with tumor cells' death by necrosis or apoptosis. However, the emergence of drug resistance has made many of the currently available chemotherapeutic agents ineffective. Consequently, the future of antitumor chemotherapy depends on the outcome of the extensive world effort aimed at the overcoming, on a rational basis, of the resistance phenomenon.

During the first decades of antitumor chemotherapy the development of resistance was, fortunately, of a specific character, addressed to particular antitumor drugs which induced a number of specific metabolic changes in tumor cells, making such drugs ineffective. These changes comprised

^Presented at the International Review Conference on Biotechnology, Vienna, Austria, November 2004.

*Equal contribution

Abbreviations and codes: ABC, ATP-binding cassette protein superfamily; BCRP, breast cancer resistance protein; $\mathrm{BSO}$, buthionine sulfoxine; DX, doxorubicin; HL-60, human promyelocytic leukemia cell line; IDA, idarubicin; LRP, lung resistance related protein-dependent resistance; MDR, multidrug resistance; MIT, mitoxantrone; MRP, multidrug resistance-associated protein-dependent resistance; MRP1, member of MRP transporters family; ODNs, oligodeoxyribonucleotides; PDZ, patent application pending; Pgp (MDR1), P-glycoprotein; RI, resistance index (ratio of $\mathrm{IC}_{50}$ (resistant cells) to $\mathrm{IC}_{50}$ (sensitive cells) where $\mathrm{IC}_{50}$ is a drug concentration causing $50 \%$ of inhibition of cell growth); RNAi, RNA interference; VINC, vincristine; $V_{\mathrm{o}^{\prime}}$ the initial velocity of cytostatic uptake. 
mostly: membrane transport (failure of drug uptake), intracellular drug distribution (lowered drug concentration at target site), structural changes of targets (loss of drug-target affinity), enhancement of detoxification systems (stimulated drug metabolism), activation of DNA repair mechanisms, and inhibition of processes inducing apoptosis. Because of the specific character of this type of resistance, it was usually possible to circumvent it by switching from one antitumor drug to another or by appropriate chemical modification of the antitumor agent.

\section{MULTIDRUG RESISTANCE OF TUMORS}

The control of tumor drug resistance dramatically worsened due to the emergence of a novel type of resistance, discovered in 1976 by Juliano and Ling, the multidrug resistance (MDR), which became a major impediment to the success of cancer chemotherapy. MDR tumor cells are crossresistant to a broad variety of chemotherapeutic agents, even chemically and functionally unrelated ones. The MDR phenomenon occurs upon expression or overexpression of a specific group of broad substrate spectrum membrane phosphoglycoproteins, capable of actively transporting diverse chemotherapeutic agents out of the cells against the concentration gradient. These drug efflux pumps operate at the expense of metabolic energy, leading to reduced intracellular drug accumulation. Consequently, MDR tumor cells can evade the cytotoxic effect of the drugs.

The phosphoglycoprotein drug efflux pumps belong to the broader group of the $\mathrm{ABC}$ superfamily of membrane transporters. It should be noted that many of them are constitutively present in various normal tissues, like epithelial cells of the colon, kidney, adrenal, pancreas or liver, which substantially complicats the development of agents which would selectively counteract the MDR phenomenon. The physiological role of $\mathrm{ABC}$ proteins comprises active transport of endo- and xeno-biotics, including detoxification processes. Consequently, tumors derived from these tissues exhibit intrinsic multidrug resistance to cytostatic agents even before chemotherapy is initiated. The MDR of tumors derived from other tissues appears phenotypically upon its induction by a cytostatic agent.

There is vast literature characterizing the chemical, biochemical and functional properties of MDR drug efflux pumps and describing their genetics. It is not the authors' aim to review this literature as we intend to concentrate on the strategies of overcoming the multidrug resistance. Therefore, in this matter, we refer the readers to selected original publications and recent review articles (Riordan \& Ling, 1979; Chen et al., 1986; Azzaria et al., 1989; Ambudkar et al., 1992; 1999; Cole et al., 1992; Gottes- man \& Pastan, 1993; Muller et al., 1994; Fardel et al., 1996; Seelig, 1998; Dalton \& Scheper, 1999; Konig et al., 1999; Maliepaard et al., 1999; Orlowski \& Garrigos, 1999; Borst et al., 2000; Litman et al., 2000; 2001; Scheffer et al., 2000; Dean et al., 2001a; 2001b; Loo \& Clarke, 2001; Gottesman, 2002; Gottesman et al., 2002; Hagenbuch et al., 2002; Schinkel \& Jonker, 2003; Yang et al., 2003; Haimeur et al., 2004). However, we think it useful to shortly summarize the current status of knowledge on the phosphoglycoprotein drug efflux pumps.

The most studied, best characterized, and of clinical importance is the first discovered multidrug transporter, named P-glycoprotein and abbreviated as Pgp or MDR1 protein, encoded by the MDR1 gene (Chen et al., 1986; Gottesman \& Pastan, 1993; Ambudkar et al., 1999). The 170-kDa P-glycoprotein has an overall molecular architecture similar to that of all ABC transporters. The Pgp molecule is composed of two halves, each consisting of transmembrane $\alpha$ helices and the cytoplasmic ATP-binding domain. The two halves are joined by a single polypeptide chain. The protein molecule contains also the substrate(s) binding domain(s). The transmembrane regions form the drug translocating pathway (Loo \& Clarke, 2001), while the ATP-binding sites, exhibiting ATPase activity, provide the metabolic energy upon ATP hydrolysis enabling the active drug efflux (Azzaria et al., 1989; Ambudkar et al., 1992). ATP hydrolysis induces, after binding of the substrate, conformation changes of the protein molecule, expelling out of the cell the substrate(s) (Gottesman \& Pastan, 1993). Although the crystal structure has been elucidated only for an ABC transporter protein of bacterial origin, nevertheless it helped to construct a structural model for the open conformation of the MDR1 P-glycoprotein, contributing essentially to better understanding of the molecular mechanism of transporter functioning (Seigneuret \& Garnier-Suillerot, 2003). The broad substrate spectrum of Pgp comprises preferably neutral or cationic amphiphilic organic compounds. The recognition of multiple substrates is based on their particular structural features (Seelig, 1998). Of importance are the number, strength and spacial location of electron-donoring groups for hydrogen bonding with hydrogen donors from defined amino-acid sequence in P-glycoprotein. The structure-activity relationships were concerning the substrate-Pgp interaction also studied by QSAR analysis (Litman et al., 1997a). The Pgp transporter is intrinsically present in the intestine, liver, kidney and blood-brain barrier.

Other ABC multidrug transporters comprise MRP and BCRP proteins (Schinkel \& Jonker, 2003). The most studied of them and of growing clinical importance are the MRP transporters. They constitute a family of, up to now, nine isoformic members (Konig et al., 1999; Borst et al., 2000; Yabuuchi 
et al., 2001; Gottesman, 2002; Haimeur et al., 2004). Individual proteins are numbered successively. The most studied one and well characterized is MRP1, a 190-kDa protein. The presence in normal tissues of MRP transporters is quite widespread. Members of the MRP family are structurally and functionally similar to Pgp, however, they differ from the latter as concerns their direct substrates. The substrate spectrum of cytostatic agents is similar to that of Pgp but MRPs, being organic anion transporters, mediate the efflux of these drugs mainly after formation of anionic drug conjugates with glutathione, glucuronate or sulfate, upon the action of appropriate transferases. The most important and studied are the S-conjugates with glutathione (Cole et al., 1992; Muller et al., 1994; Jedlitschky et al., 1996). MRP proteins can also mediate drug efflux by their cotransport with glutathione (Renes et al., 1999).

The BCRP is $95-\mathrm{kDa}$ phosphoglycoprotein drug transporter with a somewhat different structure. Unlike Pgp and MRP it contains only one transmembrane and one ATP binding domain. Therefore it is also called a "half transporter" (Doyle et al., 1998). Its drug substrate spectrum and mechanism of drug transport are quite similar to those of Pgp.

In the recent years another type of drug transporter has been recognized which is not associated with the cytoplasmic membrane, but operates by controlling the drug transport from the nucleus to the cytoplasm via vaults. This is a $110-\mathrm{kDa}$ vault protein, the lung resistance protein (LRP) (Izquierdo et al., 1996; Dalton \& Scheper, 1999; Scheffer et al., 2000). Its drug substrate spectrum is similar to that of Pgp.

\section{STRATEGIES TO OVERCOME MDR IN CANCER CELLS}

The design of nontoxic agents that would overcome the MDR of tumors has been a challenging area for pharmaceutical development. This world-wide effort combines various strategies, based on diverse mechanisms and effects. These strategies use two general approaches: (i) rational design of agents that retain their cytostatic activity towards MDR tumor cells, and (ii) development of augmenting compounds able to restore the cytotoxicity of available antitumor drugs against resistant cells. The latter approach is aimed at interfering with either the expression of the transporter proteins or their functioning.

\section{CONTROL OF EXPRESSION OF MDR PROTEINS}

Most of the information available concerns the MDR1 gene. Since its amplification is not a prerequi- site for Pgp-related resistance in human tumor cells (Ohishi et al., 2002), the potential targets of gene expression inhibition can be either RNA or protein.

The literature on the structure, function and expression of the MDR1 gene was recently reviewed (Scotto \& Johnson, 2001). Its promoter activity is upregulated by various stimuli, including cytostatics. However, of interest for the MDR problem is the possibility of down-regulation of MDR gene expression.

Relevant studies have not yet reached the level of clinical importance; however, some interesting and promising observations have been made that point to some novel possibilities of interfering with the transporter protein expression.

An MDR1 specific polypeptide transcriptional repressor has been screened out (Bartsevich \& Juliano, 2000). Modification of MDR1 promoter region was achieved by 5-azacytidine (Efferth et al., 2001). In consequence, the transcriptional activity was inhibited, and resistant K562 cells were transformed to a non-MDR type. Interesting results were obtained with ecteinascidin 743, an isoquinoline derivative of marine origin (D'Incalci, 1998). This cytostatic agent of high activity selectively inhibits the activation of induced MDR1 gene blocking its transcription, without affecting constitutive MDR1 expression (Jin et al., 2000; Scotto \& Johnson, 2001). Another example of targeting an MDR1-specific transcription factor is HMN-176, an active metabolite of the antitumor agent HMN-214, a stilbazole derivative (Tanaka et al., 2003). Its action restores the chemosensitivity of MDR cells. Attention should also be drawn to the interesting results obtained with a designed transcriptional repressor targeted to the MDR1 promoter, whose action results in the inhibition of MDR1 gene transcription ( $\mathrm{Xu}$ et al., 2002). The authors also reviewed the alternative therapeutic strategy based on selective inhibition of Pgp expression by targeting $M D R 1$-specific transcription factors.

A lot of attention has been paid to the control of MDR protein expression at the level of interference with mRNA by the antisense strategy. The formation of duplexes with the target mRNA by complementary oligodeoxyribonucleotides (ODNs) causes interruption of translation and transformation of resistant tumor cells to the non-MDR type. The major problems concerning the application of antisense strategy comprise the specificity of the ODNs for the chosen RNA target, the susceptibility to blood serum nucleases, and cellular uptake with the application of appropriate vectors (reviewed in: Crooke, 1992; Walder \& Walder, 1988; Garcia-Chaumont et al. 2000). Although the usefulness of the antisense strategy for the reduction of expression of MDR proteins has not been confirmed in animal experiments yet, the accumulated knowledge (Cucco \& Calabretta, 1996; Stewart et al., 1996; Alahari et al., 
1998; Gao et al., 1998; Volm, 1998; Astriab-Fisher et al., 2000; 2002; 2004; Pakunlu et al., 2003; Kang et al., 2004; Matsumoto et al., 2004) and patent literature (Ojima et al., 1998) on this matter point to the potential applicability of the antisense strategy approach in reversing MDR.

Another means of affecting a target mRNA is to use catalytic RNA, a ribozyme (Phylactou, 2001). Ribozymes are small RNA molecules (30-40 nucleotides) that hybridize to a complementary sequence of mRNA and catalyze site-specific cleavage of the substrate. Anti-MDR ribozymes, introduced into the cells, can reverse MDR by cleavage of MDR1 and MRP mRNA (Masuda et al., 1998; Kobayashi et al., 1999; Wang et al., 1999; Nagata et al., 2002; Wang et al., 2003).

Effects similar to the action of ribozymes in reversing MDR were obtained by the RNA interference (RNAi) approach, named also post-transcriptional gene silencing, induced by siRNA. RNAi is a conserved biological response to double-stranded RNA, which results in sequence-specific gene silencing (Hannon, 2002). The introduction of an MDR1targeted small (21 nucleotides) siRNA duplex into MDR cancer cells inhibits specifically the expression of MDR1 by causing degradation of the complementary MDR1 mRNA (Wu et al., 2003). Gene silencing induced by RNA interference has been shown to be specific and potent. siRNAs target the expression of the genes from which the siRNA sequences are derived without detectable effects on the expression of unrelated genes (Fire et al., 1998; Elbashir et al., 2001). Thus the RNAi approach may offer an alternative strategy for overcoming MDR, especially so because of the high selectivity, although its use is limited as the silencing effect on Pgp expression is short-lived, not exceeding $24 \mathrm{~h}$ (Hannon, 2002). Because the halflife of Pgp is 14-17 h (Muller et al., 1995), a greater decrease in Pgp expression may be attained through the use of a DNA vector-based siRNA expression system (Paddison et al., 2002; Sui et al., 2002).

Expression of MDR genes is governed by appropriate signals. Inhibition of signal transduction can thus be another potential approach to reverse the MDR phenotype. At the moment not much is known about this matter, however, some interesting information concerning signals for Pgp induction is available (Yang et al., 2001).

The posttranslational modifications of $\mathrm{ABC}$ transporter proteins may provide an alternative group of potential targets for MDR reversal. The protein modifications comprise $\mathrm{N}$-glycosylation and phosphorylation. Pgp is N-glycosylated at one position on the first extracellular loop of the C-terminal. Although the use of a glycosylation inhibitor (tunicamycin) and of mutant MDR cells has shown that glycosylation of Pgp is not a prerequisite for its multidrug transport function (Endicott \& Ling, 1989;
Ichikawa et al., 1991; Gottesman \& Pastan, 1993; Schinkel et al., 1993), it has been suggested that Nglycosylation may contribute to the correct folding, proper routing or stabilization of the Pgp molecule. Perhaps a better perspective for drug development may be provided by inhibitors of protein phosphorylation (Glazer, 1998). Pgp can be phosphorylated by a variety of serine/threonine kinases, such as protein kinase C (PKC), cAMP-dependent protein kinases, and calmodulin-dependent protein kinases (reviewed in: Ford, 1996; Volm, 1998; Idriss et al., 2000; Szabo et al., 2000; Wiese \& Pajeva, 2001). Phosphorylation occurs at the cytoplasmic linker region joining the halves of the Pgp molecule. This last step in posttranslational modification is indispensable for the transporter activity of Pgp, thus making protein kinases potential targets for MDR reversal. However, there is a serious problem with the selectivity of kinase inhibitors (Gupta et al., 1996; Wielinga et al., 1997; Castro et al., 1999; Conseil et al., 2001). Also the present knowledge concerning the role of the different phosphorylation states for the functioning of Pgp is rather limited. Inhibitors of PKC, such as $\mathrm{H}-87$, staurosporine and their derivatives are able to reverse MDR effectively (Sato et al., 1990). Simultaneously many compounds that can modulate MDR have also been shown to inhibit PKC (Aftab et al., 1991). Perhaps selective inhibition of Pgp phosphorylation will be more likely with the use of some peptides able to selectively inhibit PKC- $\alpha$ (Gupta et al., 1996). These peptides contain a sequence corresponding to the pseudosubstrate region of PKC- $\alpha$, and consequently are able to inhibit this enzyme. The phosphorylation step in the expression of active MDR transporters also concerns the MRP1 protein (Sato et al., 1990). Protein kinase inhibitors reduce the phosphorylation of this transporter and inhibit its activity (Gekeler et al., 1995; Ma et al., 1995).

\section{OVERCOMING THE FUNCTIONING OF MDR MEMBRANE TRANSPORTER PROTEINS}

There are several general strategies to circumvent the drug efflux action of expressed MDR transporter proteins: (i) development of compounds that are not substrates of the efflux pump(s), (ii) use of agents that inactivate (inhibit) MDR proteins, (iii) design of cytostatics characterized by fast cellular uptake, surpassing their MDR-mediated efflux, (iv) use of compounds competing with a drug for the MDR protein mediated efflux. Some additional specific strategies have also been applied for overcoming MRP and LRP resistance. The reduction of MRP resistance can be also achieved by affecting the intracellular formation of anionic drug conjugates. The formation of such conjugates with glutathione can be indirectly inhibited by buthionine sulfoximine (BSO), 
a potent inhibitor of glutathione synthesis (Griffith \& Meister, 1979), or by the inhibition of glutathione reductase by $N, N$-bis(2-chloroethyl)- $N$-nitrosourea (BCNU) (Vanhoefer et al., 1997). Inhibition of drug transport from the nucleus to the cytoplasm, mediated by LRP protein, was achieved with the PAK$104 \mathrm{P}$ inhibitor, a pyridine derivative (Kitazono et al., 2001).

The final effects of the general strategies illustrated in Fig. 1 comprise: drug influx with no or reduced efflux (strategies (i) and (ii), Fig. 1A), drug influx surpassing its efflux (strategy (iii), Fig. 1B), and competitive inhibition of drug efflux (strategy (iv), Fig. 1C). All these effects lead to the retaining
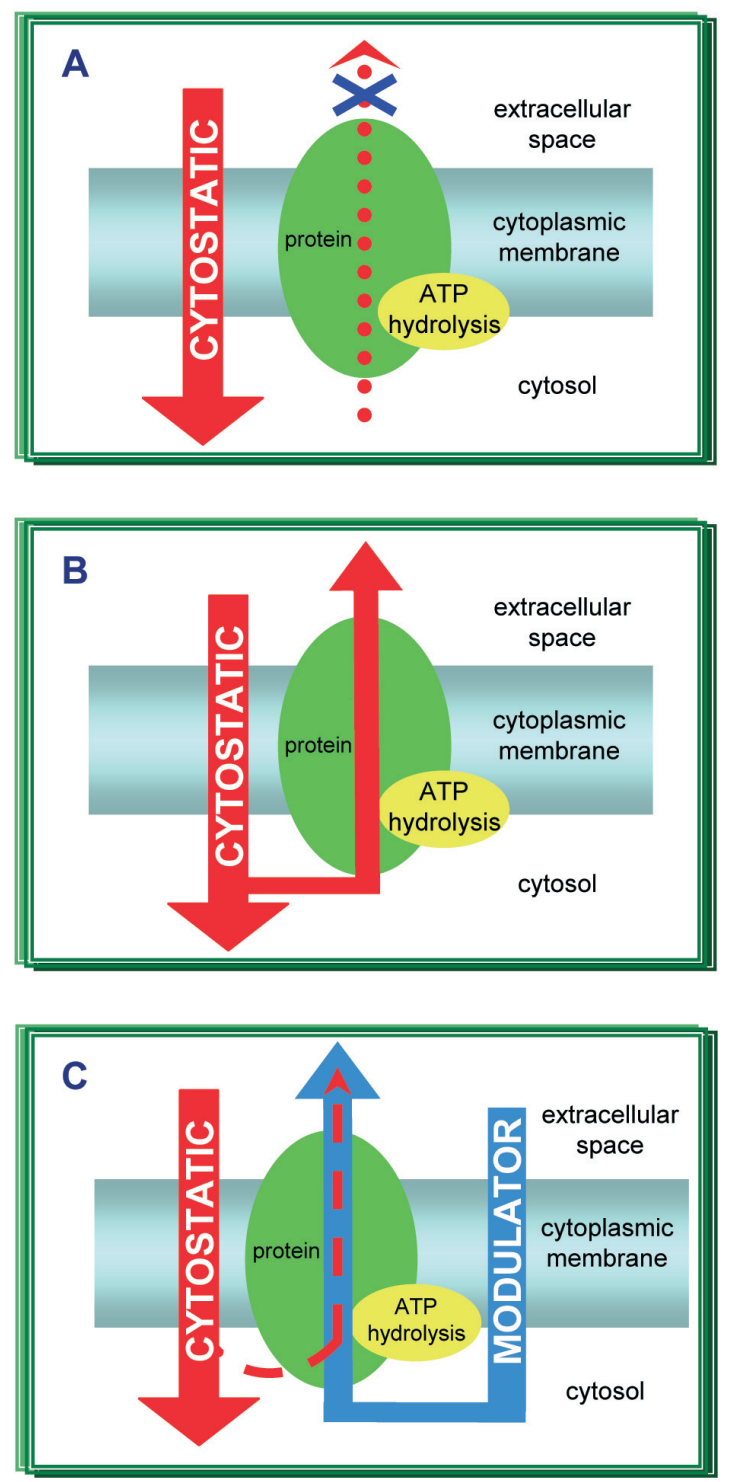

Figure 1. Three types of drug cellular migration events in overcoming MDR.

A, influx without mediated efflux; B, influx surpassing mediated efflux; $\mathrm{C}$, competitive modulator action. Borowski E, Bontemps-Gracz MM, Piwkowska A (2004) Biotechnology International Review Conference, November 14-18, 2004, Vienna, Austria. Abstracts, Abstract C-10. in MDR tumor cells of a therapeutic concentration of the drug.

Strategies (ii) and (iv) are of the combination therapy type requiring the use of more than one active agent: the cytostatic drug and an augmenting agent. Regardless of the type of action of the latter ones (reversible, irreversible, competitive, noncompetitive), these compounds bear interchangeable names: MDR-modulators, inhibitors, chemosensitizers, reversing agents. This is quite misleading, as these names do not refer directly to the mechanism of MDR overcoming.

It is important to note that the use of MDR modulators, albeit beneficial, could also have undesirable side effects in vivo because the ABC proteins are expressed also in normal tissues, such as the adrenal, gravid uterus, kidney, liver, colon and capillary and the capillary endothelial cells in the brain (Thiebaut et al., 1987; Ambudkar et al., 1992; Tatsuta et al., 1992). MDR modulators could block their normal physiological function. Additionally, such chemosensitizers could cause increased toxic effects by inhibiting the efflux of the cytotoxic agent mediated by the $A B C$ proteins in normal tissues. Therefore in designing all types of MDR-reversing agents selectivity of their action is of paramount importance.

Regarding these obstacles the nonsubstrate strategy has an advantage of not disturbing the physiological functioning of the $\mathrm{ABC}$ proteins in normal tissues. However, this strategy has strong limitations, as MDR proteins exhibit a very broad substrate spectrum comprising many groups of chemicals and it is very difficult to identify nonsubstrate ones. Nevertheless some such compounds have been found in random testing. Although they represent diverse chemical types, attempts have been made to find a rationale for their structural and physicochemical characteristics (Litman et al., 1997a; Seelig, 1998). Some examples of more important cytostatics which are not recognized as substrates by MDR pumps comprise: paclitaxel - not a substrate of MRP1 (Huang et al., 1997), lamellarin D - not a Pgp substrate (Vanhuyse et al., 2005), epothilone B - not recognized by either Pgp or MRP (Chou et al., 1998), and camptothecin derivatives - poor substrates for BCRP (Perego et al., 2001). A systematic search for "non-substrate" compounds yielded several other products (Gottesman et al., 2002). Special consideration should be given to MRP non-substrates. Such compounds are very rarely found in comparison with non-substrate of other MDR transporters. Also the mechanism of overcoming MRP by this type of agents has not been unambiguously elucidated yet. Unlike with other transporters the substrate properties concerning MRP should be considered regarding two processes: transferase reactions generating the anionic drug conjugates and their binding to the MRP transporter. 
The only broader group of MDR non-substrates comprises antimetabolites. Although these cytostatics are considered as MDR-overcoming drugs, the reasoning behind this classification has not been clearly defined. MDR transporters, albeit of a very broad substrate spectrum, recognize cellular components and metabolites indispensable for the cell function as endobiotics, the compounds which should not be effluxed. Thus antimetabolite, as close metabolite analogues mimicking the endobiotic cellular components, should not be recognized by the transporters as xenobiotics.

There is little literature dealing with the mechanism of overcoming MDR by antimetabolites. It has been evidenced that 5-fluorouracil (Zeng et al., 2004; Jin et al., 2005), 5-fluorouridine (Zeng et al., 2004), gemcitabine (Bergman et al., 2001), cytarabine (Hait et al., 1993; Bergman et al., 2001; Lofgren et al., 2004;), 6-thioguanine (Hait et al., 1993), and methotrexate (Litman et al., 2001), are not substrates of Pgp. Cytarabine is not a substrate of the BCRP transporter either (Stam et al., 2004). Dideoxynucleosides are not recognized by Pgp in kidney transport (Leung \& Bendayan, 1999). It is unfortunate that some antimetabolites, such as 6-methylguanine, 3-deazauridine, tiazofurine, while retaining their cytotoxicity towards cells expressing $A B C$ proteins, behave in part as xenobiotics so that they induce the overexpression of genes encoding these proteins, thus increasing resistance to other antitumor drugs ( $\mathrm{Lu}$ et al., 2002). Metabolic modification of antimetabolites can affect their substrate properties for MDR transporters. Methotrexate is a good substrate for the MRP protein in short treatment, but on prolonged exposure to the drug polyglutamylation occurs and the modified drug is no more effluxed (Jansen et al., 1999; Kruh et al., 2001). On the other hand, cytarabine is not cytotoxic for MRP expressing cells as it is effluxed as a conjugate formed with glutathione. Preincubation of cells with BSO, an inhibitor of glutathione synthesis, restores cytarabine cytotoxicity (Takemura et al., 2001).

It is unfortunate that for this important group of MDR-overcoming antitumor drugs no systematic studies have been performed concerning the role of structural factors in their substrate properties for various MDR transporters. We have shown that antimetabolites which structurally differ considerably from their natural equivalents are, to a lesser or greater extent, recognizable by MDR transporters and are effluxed (see legend to Fig. 1: Borowski et al., 2004). Some results obtained by other authors can be interpreted in the same way. The deeply modified folic acid analogues ZD1694 and GW1843 are good substrates for MRP proteins (Hooijberg et al., 1999). The same effect was also observed with modified nucleoside analogues which were effluxed by MRP4 and MRP5 (Borst et al., 2000).
Beside the "non substrates" concept and inhibition of formation of anionic conjugates with MRP substrates, either by the inhibition of glutathione synthesis or by affecting the activity of appropriate transferases, the final effect of drug influx without its efflux can be also achieved by inhibition or inactivation of the MDR transporter proteins. This approach comprises allosteric inhibition and irreversible (covalent) or reversible inactivation of transporter proteins. Most of the accumulated knowledge on this matter concerns the Pgp transporter.

The substrate-drug binding behavior of Pgp is complex, with several binding sites involved. They comprise transport sites, where translocation of the drug substrate across the lipid bilayer can occur, and regulatory sites which modulate Pgp function. Pgp modulators fall into two types: those that are transported and those that are not. Competitive and noncompetitive kinetics are observed for different modulators. Modulators which bind to Pgp but failing transport prevent the transport of other agents (Dey et al., 1997; Litman et al., 1997b; Scala et al., 1997; Martin et al., 2000).

Allosteric mechanism of inhibition of Pgp has been shown for several modulators (Maki et al., 2003). One of them is cis-(Z)-flupentixol, a thioxanthene derivative. This compound does not interfere with substrate recognition by Pgp, but prevents substrate translocation and dissociation by allosteric modulation of human Pgp. Several anthranilic acid derivatives modulate Pgp-mediated transport by an allosteric effect on substrate recognition or ATP hydrolysis (Martin et al., 1997; 1999). Similarly, indolizin sulfone SR33557 affects substrate binding to Pgp through interaction with a site other than the substrate recognition one (Martin et al., 1997). Some other modulators like dexniguldipine and prenylamine inhibit interaction of other drugs with Pgp by a noncompetitive mechanism (Ferry et al., 1995; Boer et al., 1996). An interesting group of Pgp nontransportable inhibitors are flavonoids. These compounds interact with cytosolic domains of Pgp and its ATP binding sites, inhibiting the ATPase activity of this protein (Conseil et al., 1998; Choi et al., 2004).

Several covalent inhibitors of Pgp have been studied. Some ATP analogues, including photoaffinity labels, block the nucleotide binding domains and inhibit the ATPase activity of Pgp. The photoaffinity analogues react with a lysine residue in the nucleotide binding domains. There is some chance for selectivity in the inhibition of ATP hydrolysis because the catalytic sites in Pgp are conformationally flexible and of relatively low affinity and specificity compared to other transport ATPases (Al-Shawi et al., 1994). Interesting results were obtained with a nonnucleotide type covalent inhibitor of Pgp ATPase activity, 7-chloro-4-nitrobenzo-2-oxa-1,3-diazole (NBD$\mathrm{Cl})$. The inhibition occurs already after the inhibitor 
binds to the ATP-binding catalytic site in a 1:1 molar ratio, indicating that the inactivation of only one of the two Pgp nucleotide binding sites is sufficient for complete inactivation. This is understandable, as both ATP-binding sites are indispensable for the transport activity due to the alternating cooperative supply of energy by both sites (Al-Shawi \& Senior, 1993; Senior \& Bhagat, 1998; Senior et al., 1998).

The "non substrate strategy" in overcoming MDR is of interest also because it enables the advantageous monotherapy treatment, not requiring the use of any augmenting agents. The same desirable effect can be also obtained by the design of cytostatics with a cellular uptake faster than their mediated efflux (strategy (iii), Fig. 1B). Drug uptake can occur via: (1) diffusion, e.g., doxorubicin, (2) mediated transport, e.g., nucleoside analogues, (3) endocytosis, e.g., immunotoxins (Gottesman, 2002). The most desirable and most frequent is drug uptake by simple diffusion across the lipidic cytoplasmatic membrane. The kinetics of diffusion is linearly concentration dependent. On the other hand, the MDR transporters mediated drug efflux is not linear and is of saturation kinetics type. Thus compounds characterised by very fast influx, faster than their mediated efflux at the transporters' saturation point, could be retained in cells in desirable concentration. It has been generally accepted that the lipophilicity of drugs is a factor favoring their uptake by diffusion. However, the increase of lipophilicity of cytostatics by appropriate chemical modification is not sufficient to achieve the goal. In our studies we have shown that in drug migration across the membrane not only the lipophilic- ity, but to a great extent also structural factors as such are of essential importance. We have identified such factors in two important groups of cytostatics, namely anthraquinone and acridine compounds (Stefanska et al., 1999). According to our concept, the inclusion into their molecules of one or two fused five- or six-membered heterocyclic ring(s) makes these molecules able to overcome MDR. This is an indispensable qualitative factor, while the modification of lipophilicity of such compounds by appropriate substituents can further quantitatively influence their activity towards MDR cells. This hypothesis has led to the development of several novel groups of active polycyclic anthraquinone and acridine analogues (Fig. 2 and references there). It has been evidenced that polycyclic compounds of such type overcome MDR due to the speed of their uptake surpassing the rate of MDR transporters-mediated efflux (Tkaczyk-Gobis et al., 2001; Tarasiuk et al., 2002; 2004; Fig 1: Borowski et al., 2004). The cytotoxic activity of representative compounds (Fig 1: Borowski et al., 2004) from several groups of polycyclic anthraquinone and acridine analogues towards Pgp and MRP cell lines is presented in Fig. 3. It should be noted that the compounds examined have very favorable resistance indexes in both types of resistant cells, as compared to those of the reference compounds doxorubicin and mitoxantrone. As exemplified in Fig. 4A the initial velocities of uptake and cellular accumulation of a tetracyclic anthraquinone analogue in sensitive cells are much better than in the case of the reference tricyclic idarubicin. An exemplary experiment with a pentacyclic acridine ana-

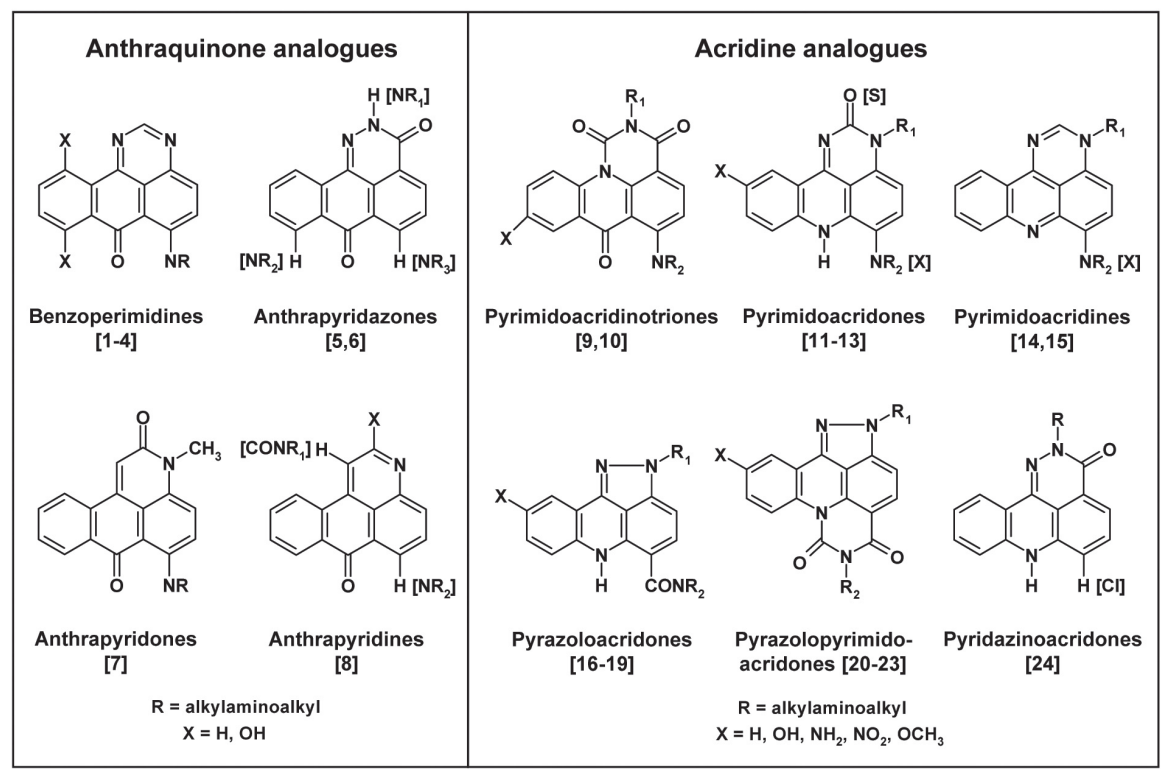

Figure 2. The structures of MDR-overcoming anthraquinone and acridine compounds.

[1-4] Stefanska et al., 1993; 1999; Tkaczyk-Gobis et al., 2001; Dzieduszycka et al., 2002; [5, 6] Stefanska et al., 2003; Fig 1: Borowski et al., 2004; [7] Tarasiuk et al., 2002; [8] Dzieduszycka et al., 2005; [9,10] Antonini et al., 1995; 1999a; [11-13] Antonini et al., 1996; 1999b; Fig 1: Borowski et al., 2004; [14, 15] Antonini et al., 1999b; Fig 1: Borowski et al., 2004; [16-19] Antonini et al., 2001; Bontemps-Gracz et al., 2002; Tarasiuk et al., 2004; Fig 1: Borowski et al., 2004; [20-23] Antonini et al. 2002; Bontemps-Gracz et al., 2002; Tarasiuk et al., 2004; Fig 1: Borowski et al., 2004; [24] Stefanska et al., 2005. 


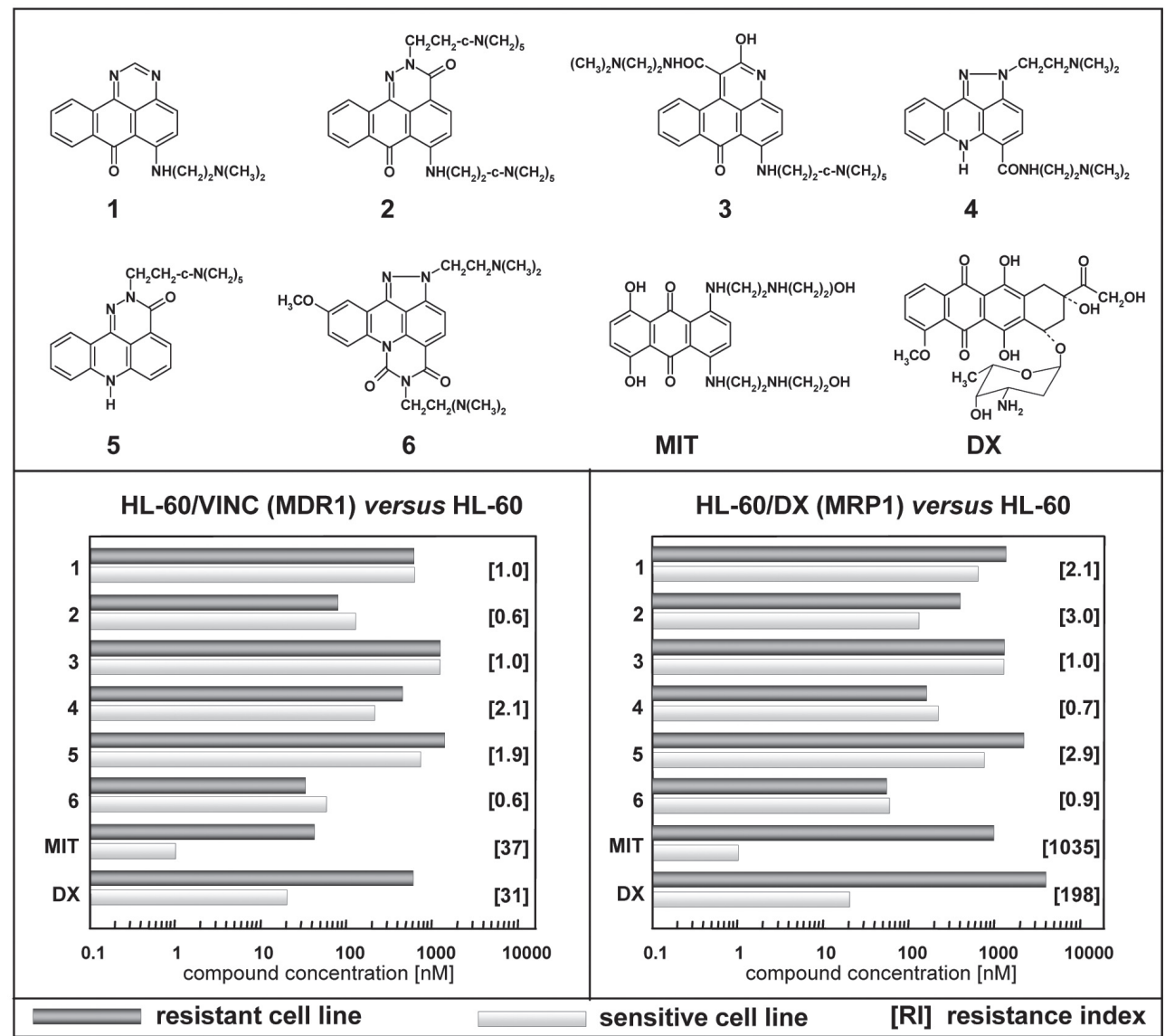

Figure 3. Resistance indexes for representative anthraquinone and acridine compounds (Fig. 1: Borowski et al., 2004). The cytotoxic activity in vitro was determined by cell counting or by protein content of the cells (Bontemps-Gracz et al., 1991) after $72 \mathrm{~h}$ of continuous exposure to the cytostatic.

logue (Fig. 4B) shows that its uptake characteristics are practically identical in sensitive as well as in Pgp- and MRP1-expressing cells.

Competitive MDR modulators are the most studied and most advanced in the design of agents of potential importance, essentially contributing to overcoming multidrug resistance of tumors. Being MDR pumps' substrates these compounds compete with cytostatics for the MDR transporter proteins, thus inhibiting the efflux of the latter (Fig. 1C). This strategy was established following the pioneering studies of Tsuruo and coworkers in 1981 and the discovery of the activity of the first competitive MDR modulator verapamil. Since then, abundant literature has become available describing numerous competitive MDR modulators, to a lesser or greater extent restoring the cytotoxic activity of cytostatics against MDR tumor cells. Active agents belong to very diverse chemical groups and exhibit varied properties in respect to their selectivity for various target $\mathrm{ABC}$ transporters and undesirable side-effects. The abundance of this literature prompts us to refer the readers to selected more recent review (Volm, 1998; Krishna \& Mayer, 2000; 2001; Lehne, 2000; Dantzig et al., 2001; Avendano \& Menendez, 2002; Liscovitch \& Lavie, 2002; Teodori et al., 2002; Kawase \& Moto- hashi, 2003; Robert \& Jarry, 2003; Kellen, 2003; Lee, 2004). The development of these agents was aided by the application of the combinatorial chemistry approach, identification of physiochemical requirements, SAR analysis and QSAR methods (Zamora et al., 1988; Ojima et al., 1998; Kim, 2001; Wiese \& Pajeva, 2001). The development of active chemical compounds as MDR modulators was accompanied by extensive biological, biomedical and pharmacological studies, as well as clinical trials (reviewed in Sandor et al., 1998; Ambudkar et al., 1999; Tan et al., 2000; van Zuylen et al., 2000; Toppmeyer et al., 2002; Dantzig et al., 2003; Goldman, 2003; Mizuno et al., 2003; Thomas \& Coley, 2003).

Regarding the positive features and the negative side-effects of the examined compounds, three generations of MDR modulators have been distinguished. Compounds discovered by random screening constitute first generation agents (e.g., cyclosporin A, verapamil). They exhibit poor modulatory activity and unacceptable toxicity when used in higher doses (Krisha \& Meyer, 2000; Schinkel \& Jonker, 2003). Many of them are also substrates for other $\mathrm{ABC}$ transporters and enzyme systems, resulting in unpredictable pharmacokinetic interactions in the presence of chemotherapeutic agents. 
Table 1. MDR modulators of 2 nd and 3rd generation in clinical trials

\begin{tabular}{|c|c|c|c|c|}
\hline Modulator & Structure & Target & Trials phase & Reference \\
\hline $\begin{array}{c}\text { PSC833 } \\
\text { Valspodar } \\
\text { (cyclosporin D } \\
\text { derivative) }\end{array}$ & & Pgp & III & 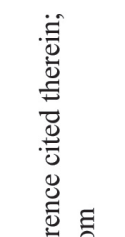 \\
\hline $\begin{array}{c}\text { MS209 } \\
\text { (quinoline } \\
\text { derivative) }\end{array}$ & & $\begin{array}{l}\text { Pgp } \\
\text { MRP }\end{array}$ & I / II & 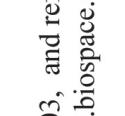 \\
\hline $\begin{array}{c}\text { VX710 } \\
\text { Biricodar } \\
\text { Incel } \\
\text { (pipecolinate } \\
\text { derivative) }\end{array}$ & & $\begin{array}{l}\text { Pgp } \\
\text { MRP } \\
\text { BCRP }\end{array}$ & II & 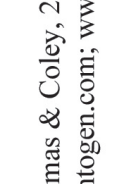 \\
\hline $\begin{array}{c}\text { XR9576 } \\
\text { Tariquidar } \\
\text { (anthranilamide } \\
\text { derivative) }\end{array}$ & & $\begin{array}{l}\text { Pgp } \\
\text { MRP }\end{array}$ & I / II / III & 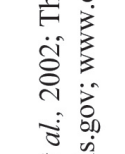 \\
\hline $\begin{array}{c}\text { LY335979 } \\
\text { RS-33295-198 } \\
\text { Zosuquidar } \\
\text { (dibenzosuberane } \\
\text { derivative) }\end{array}$ & & Pgp & II / III & 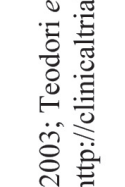 \\
\hline $\begin{array}{l}\text { GF120918 } \\
\text { GG918 } \\
\text { Elacridar } \\
\text { (acridone } \\
\text { carboxamide } \\
\text { derivative) } \\
\end{array}$ & & $\begin{array}{l}\text { Pgp } \\
\text { BCRP }\end{array}$ & I & 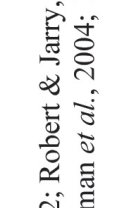 \\
\hline $\begin{array}{l}\text { R-101933 } \\
\text { Laniquidar } \\
\text { (benzazepine } \\
\text { derivative) }\end{array}$ & & Pgp & II / III & 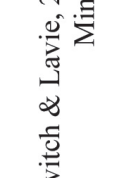 \\
\hline $\begin{array}{c}\text { ONT093 } \\
\text { OC144-093 } \\
\text { (diarylimidazole } \\
\text { derivative) }\end{array}$ & & Pgp & I / II & 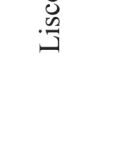 \\
\hline
\end{tabular}

Second generation modulators exhibit much improved properties, to such an extent that some of them have reached the level of clinical trials. These compounds came not only from random screening but also from appropriate chemical modifications of 1st generation compounds. Also effective compounds, of novel structural types have been identified. Second generation modulators, like verapamil analogues, valspodar (nonimmunosuppressive analogue of cyclosporin), and biricodar, exhibited a higher modulatory activity and were less toxic, but still were unacceptable due to pharmacokinetic interactions with other transporter proteins. Modula- tors of third generation exhibit essential improvement in the effectiveness and pharmacological profile. They include tariquidar, zosuquidar, laniquidar and ONT093. These compounds exhibit high MDR modulatory potency, selectivity for target MDR transporter(s), low toxicity, and lack of pharmacokinetic interactions. Selected optimal compounds of the 2nd and 3rd generations are undergoing intensive clinical trials (Table 1), however, none of them, as yet, has been registered for routine clinical use.

Perspectives for success in overcoming MDR of tumors by the application of MDR modulators are quite optimistic; however, this is not yet the 


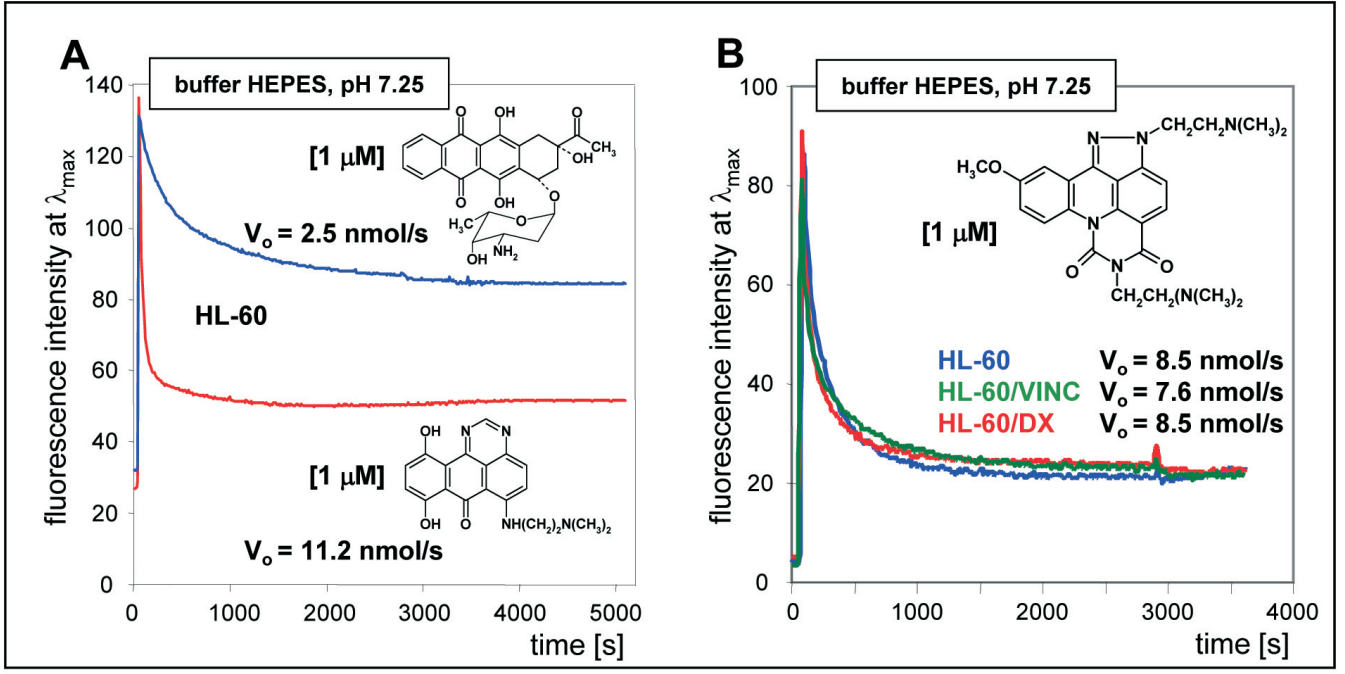

Figure 4. Uptake characteristics of cytostatics (as in Fig. 1: Borowski et al., 2004).

The initial influx velocities and accumulation of A, benzoperimidine and reference idarubicin (sensitive cells); B, pyrazolopyrimidoacridone (sensitive, MDR1 and MRP1 resistant cells). Drug migration followed by fluorimetric method (Tarasiuk et al., 1989).

end of this story. The search for still more effective compounds, with a better selectivity and pharmacological profile should be continued. Perhaps of importance in this endeavor should be broadening by medicinal chemists of the panel of structural types

Table 2. Restoration of in vitro cytotoxic activity of clinical cytostatics by modulator PDZ used in nontoxic concentration $13.5 \mathrm{nM}$ (as in Fig. 1: Borowski et al., 2004)

\begin{tabular}{|c|c|c|c|}
\hline \multirow{2}{*}{ Cytostatic } & & \multicolumn{2}{|c|}{ Resistance index RI } \\
\hline & & $\begin{array}{l}\text { HL-60/VINC } \\
\text { MDR1 resi- } \\
\text { stance }\end{array}$ & $\begin{array}{l}\text { HL-60/DX } \\
\text { MRP1 resi- } \\
\text { stance }\end{array}$ \\
\hline \multirow[t]{2}{*}{ Actinomycin D } & alone & 39.73 & 27.00 \\
\hline & with PDZ & 1.25 & 4.25 \\
\hline \multirow[t]{2}{*}{ Doxorubicin } & alone & 32.26 & 216.10 \\
\hline & with PDZ & 1.29 & 1.45 \\
\hline \multirow[t]{2}{*}{ Etoposide } & alone & 125.62 & 250.66 \\
\hline & with PDZ & 1.30 & 1.26 \\
\hline \multirow[t]{2}{*}{ Mitoxantrone } & alone & 33.30 & 927.40 \\
\hline & with PDZ & 1.44 & 1.22 \\
\hline \multirow[t]{2}{*}{ Taxol } & alone & 1454.28 & 1.10 \\
\hline & with PDZ & 1.13 & - \\
\hline \multirow[t]{2}{*}{ Vinblastine } & alone & 294.80 & 3.90 \\
\hline & with PDZ & 1.33 & 1.33 \\
\hline
\end{tabular}

The cytotoxic activity in vitro was determined by cell counting or by protein content of the cells (Bontemps-Gracz et al., 1991) after $72 \mathrm{~h}$ of continuous exposure to the cytostatic. of active agents, increasing the chance for the development of optimal MDR modulators.

In our studies we have identified novel structural types of competitive modulators of MDR. These are poly- (tetra- and penta-) cyclic anthraquinone and/or acridine analogues. This group of compounds was first developed as MDR-overcoming ones on the basis of a strategy discussed above and visualised in Fig. 1B. The compounds are substrates of MDR transporters. Their appropriate modifications aimed at retaining the transporters' substrate properties but diminishing their cytotoxicity gave a group of effective competitive MDR modulators. Perhaps the most interesting is the tetracyclic anthraquinone analogue PDZ (patent application pending). The compound, used in a noncytotoxic concentration, restores the cytotoxic activity of a number of clinical antitumor agents towards resistant MDR1 and MRP1 leukemic cell lines (Table 2). This effect results from the restoration of drug accumulation in the resistant cells (Fig. 5).

\section{ALTERNATIVE WAYS OF APPROACHING THE MDR PROBLEM}

In addition to the reversal of multidrug resistance by chemicals interfering either with the expression of transporter proteins or with their function, there are some other interesting strategies.

Various substances modify the fluidity of membranes, affect membrane-bound structures, and change intracellular $\mathrm{pH}$ and/or electric membrane potential. The interaction sites of transporter proteins with the lipid bilayer are mostly in lipophilic amino-acid sequence located in the transmembrane 


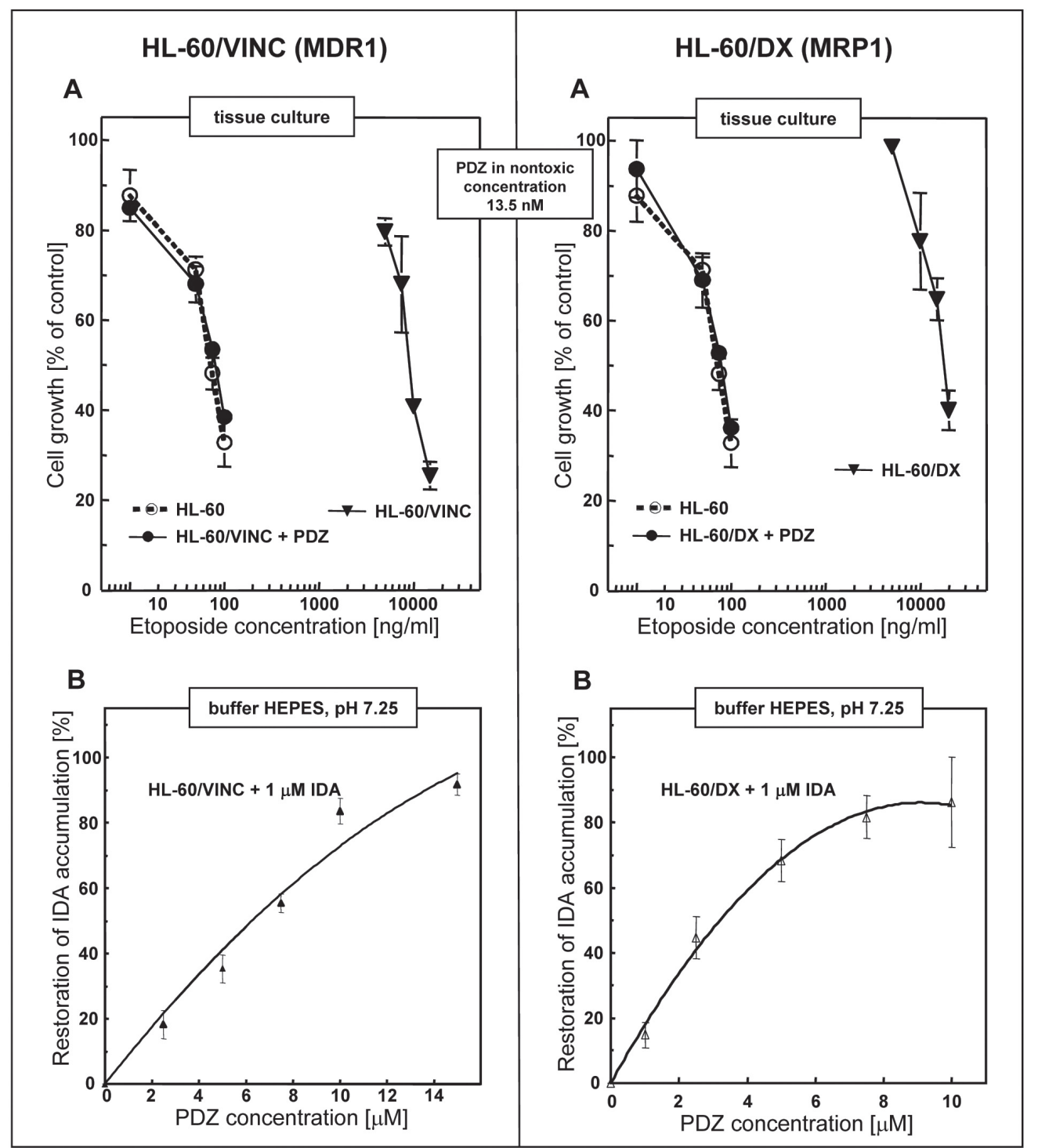

Figure 5. Restoration of cytotoxic activity and of cellular accumulation of clinical cytostatics by the modulator PDZ (as in Fig. 1: Borowski et al., 2004).

A. The cytotoxic activity in vitro was determined by cell counting or by protein content of the cells (Bontemps-Gracz et al., 1991) after $72 \mathrm{~h}$ of continuous exposure to the cytostatic. B. Idarubicin accumulation followed by fluorimetric method (Marbeuf-Gueye et al., 2000).

regions, and can be affected by chemicals modifying the membrane physicochemical properties. Membrane modifications on their own can chemosensitize MDR cells even without the use of transporter inhibitors or modulators. The action of detergents or membrane fluidization by ether, other anaesthetics, or some other agents abolishes Pgp ATPase activity and modulates efflux from multidrug-resistant cells, due to the suggested flippase activity of Pgp (Regev et al., 1999; Ferte, 2000).

Cytostatic agents cause necrotic or apoptotic tumor cell death, but it is apoptosis which plays a critical role in chemotherapy-induced tumor cells killing. The susceptibility of tumor cells to apoptosis upon treatment with cytostatics appears to depend on the balance between the proapoptotic and surviv- al (anti-apoptotic) signals (reviewed in: Tsuruo et al., 2003; Yang et al., 2003; Pommier et al., 2004; Secchiero et al., 2004). This balance is shifted in MDR cells towards the survival as a consequence of the diminished intracellular drug concentration. The advantageous balance can be restored by introducing targetspecific proapoptotic therapies. Once the apoptotic process is started it leads to the activation of the caspase cascade that in turn causes proteolytic degradation of a variety of important proteins and leads to the destruction of DNA (Fulda et al., 1998). Thus, several target sites for proapoptotic therapies can be identified (Yang et al., 2003) along the signal transduction pathway (Secchiero et al., 2004). Perhaps the most interesting as targets are proteasomes, the major site of degradation of abnormal or short-lived 
regulatory proteins, such as transcription factors or cyclins. Modulation of proteasome activity by inhibitors can affect the signal transduction pathway(s) associated with apoptosis and in consequence enhance it (Adams, 2002), thus compensating for the negative effect of the lowered concentration of a drug in MDR cells. A very promising proteasome inhibition was achieved by bortezomib (PS-341), a dipeptide boronate, which strongly stimulates apoptosis (reviewed in Yang et al., 2003). However, it should be remembered that proteasomes are expressed also in normal tissues and play essential roles in various cellular functions. Therefore, nonselective inhibition of proteasomes might have adverse effects. Moreover, the inhibitor should be able to evade the action of the MDR pump, or else an appropriate pump modulator should be used.

Another alternative approach to deal with MDR cells is based on immunological methods. Monoclonal antibodies were first used to identify the expression of Pgp (Hamada \& Tsuruo, 1986), however, they can also be applied to inhibit Pgp specifically because of their high selectivity against well defined epitopes, and the resulting ability to abolish the MDR phenotype of tumor cells (Hamada et al., 1990; Mechetner \& Roninson, 1992). The combination of anti-Pgp monoclonal antibodies with Pgp modulators may also be useful in enhancing the reversal of Pgp-mediated MDR (Watanabe et al., 1997). Monoclonal antibodies themselves also affect the proliferation of Pgp-expressing tumor cells (Tsuruo et al., 1989; Heike et al., 1990; Efferth et al., 1991; Mechetner \& Roninson, 1992). The best results were obtained in a combination therapy using a monoclonal antibody, chemosensitizers, and an antitumor drug (Naito et al., 1993a; 1993b). Also immunotoxins could be potentially valuable for the treatment of multidrug resistant cells. Their molecules consist of a monoclonal antibody coupled to a cytotoxic agent via a linker. The hybrid toxin binds to its specific target antigen and exerts its cytotoxic effect after internalization. Several such compounds have been obtained which exhibit cytotoxic activity towards Pgp-expressing cells with only marginal inhibitory effect in sensitive cells. The extent of cell killing correlated with the level of Pgp expression (FitzGerald et al., 1987; Efferth \& Volm, 1993). Of interest are also bispecific antibodies, representing chimeric proteins with each of the two antigen binding sites recognizing different antigens (Van Dijk et al., 1989). The bispecific antibodies concept may allow an improvement of selectivity towards particular tissues. The antibody-directed approaches might be promising alternatives to conventional chemotherapy of MDR tumors. However, successful drug development can only be achieved if the following three major problems are overcome: (i) the immunogenic activity of animal antibodies in humans, (ii) inadequate antibody concentration in solid tumors, (iii) lack of selectivity regarding Pgp-expressing tumors and normal cells (Hamada et al., 1990; Efferth \& Volm, 1992).

It has been shown that some protein-drug conjugates exhibit increased tumor uptake (Sinn et al., 1990; Stehle et al., 1997). Consequently, an MDRreversing effect of bovine serum albumin-conjugated doxorubicin was shown in doxorubicin-resistant tumors (Pommerenke et al., 1995).

A rather unusual and exciting concept has been put forward recently concerning the exploitation of the MDR effect for selectively killing resistant cancer cells, while sparing sensitive normal cells (Blagosklonny, 2003). The majority of current anticancer drugs attack cancer-nonspecific targets, such as DNA and microtubules, and hence do not discriminate between cancer and normal cells, resulting in harmful side effects. Many cytostatics induce apoptosis in cancer as well as in normal cells, executed by caspases (Reed, 2002). The use of a caspase inhibitor selected to be a substrate for the MDR pumps, protects normal cells from apoptosis upon the action of a cytostatic agent which, in contrast, is chosen such as not be a substrate of the drug efflux pumps. In consequence, only the MDR cells are not protected from the cell cycle inhibitor. In a model experiment (Blagosklonny, 2003), the cytostatic agent flavopiridol and the caspase inhibitor Z-DEVD-fink were used. Flavopiridol is an inducer of apoptosis (Kitada et al., 2000) and is not a good substrate of Pgp or MRP (Boerner et al., 2001; Robey et al., 2001). On the other hand, the caspase inhibitor used (Blagosklonny, 2001) is a substrate of drug transporters. In consequence, good selective toxicity was recorded using the sensitive cell line HL-60 and its Pgp and MRP1 resistant sublines. Unfortunately, normal cells with intrinsic expression of transporter proteins are expected to behave as MDR tumor ones.

Another original concept of the same author (Blagosklonny, 2003) is based on the idea of "cytostatic protectors", which would reversibly arrest the cell cycle and inhibit proliferation, thus protecting normal cells from anticancer drugs that preferentially kill cells in a particular phase of the cell cycle (Shah \& Schwartz, 2001; Gardner, 2002). The protector should be a substrate of MDR pumps, while the cytostatic agent should not (Blagosklonny, 1999).

The phenomenon of multidrug resistance enabled the development of an interesting concept for cancer gene therapy (reviewed in: Volm, 1998; Gottesman, 2002; Tsuruo et al., 2003). The MDR1 gene is expressed in several tissues, but is not widely expressed in bone marrow cells. This may be one of the reasons for severe side effects of some cytostatic agents being especially visible in bone marrow cells, which is the dose-limiting factor during the treatment of cancer patients. It may be possible to 
protect haematopoietic cells from toxic side effects of cancer chemotherapy by transducing the MDR1 gene, thus allowing the elevation of doses of cytostatics for cancer patients. For this purpose retrovirus-mediated gene transfer can be used (Pastan et al., 1988; Gottesman et al., 1994). This therapeutic approach is interesting because it could be applied to a wide range of currently resistant solid tumors.

\section{CONCLUSIONS AND PERSPECTIVES}

Multidrug resistance (MDR) of tumors is a major cause of failures in antitumor chemotherapy. Many diverse strategies for overcoming this adverse phenomenon have been proposed. The strategy based on development of MDR-modulating compounds used as augmenting agents in combination antitumor therapy is among the most promising ones. This strategy should allow the restoration of therapeutic effectiveness of already available clinical cytostatics, thus evading the threat of an apocalypse which otherwise awaits us when these cytostatics are no more effective due to the development of MDR of tumors.

Although positive effects can be expected in cancer chemotherapy by the application of MDR modulators as augmenting agents for overcoming multidrug resistance of neoplastic cells, we should be aware of various dangers accompanying their use. The major problem concerns the adverse side-effects which might occur if the modulator is not selective enough. In this respect two most important aspects should be taken into the consideration in the rational design of optimal MDR modulators.

Cytotoxic agents inducing $\mathrm{ABC}$ transporters often induce also cytochrome P450 enzymes (Lum \& Gosland, 1995). These agents, being substrates for MDR transporters, also often are metabolised by cytochrome P450 isoenzyme 3A4 in a detoxification process. Some MDR modulators can also be substrates for this enzyme. The competition between cytostatic agents and MDR transporter modulators for cytochrome P450 3A4 can results in unpredictable pharmacokinetic interactions that might lead to increased serum concentration of the cytotoxic agent and potentially put patients at risk of cytotoxic drug overexposure (Fischer et al., 1998; Rowinsky et al., 1998; Bates et al., 2001; Gottesman et al., 2002). Consequently, it may be difficult to establish safe but effective doses of the coadministered drug and the modulator.

Another problem concerning the adverse sideeffects of MDR modulators is their selectivity for the target MDR transporters. Such agents may also function as substrates for other ABC transporter proteins, inhibition of which could affect detoxification and other transport activities of normal cells and tis- sues. Many of these transporters have a well defined physiological role, often involving the elimination of xenobiotics, in specialized tissues and organs like liver, kidney, and gastrointestinal tract (Krishna \& Mayer, 2000).

Further fundamental studies should be done to better understand the mechanisms of the discussed adverse effects at the molecular level and to build a sound theoretical basis for the rational design and development of optimal agents for effective combination antitumor chemotherapy.

\section{Acknowledgements}

This work was supported by the State Committee for Scientific Research (KBN, Warszawa, Poland, grants No. 3 P05F 00324 and 2 P05F 006 26), Ministry of Science and Information Society Technologies (grant SPB), and in part by the Chemical Faculty, Gdańsk University of Technology, Poland.

\section{REFERENCES}

Adams J (2002) Proteasome inhibition: a novel approach to cancer therapy. Trends Mol Med 8: S49-S54.

Aftab DT, Ballas LM, Loomis CR, Hait WN (1991) Structure-activity relationships of phenothiazines and related drugs for inhibition of protein kinase C. Mol Pharmacol 40: 798-805.

Alahari SK, DeLong R, Fisher MH, Dean NM, Viliet P, Juliano RL (1998) Novel chemically modified oligonucleotides provide potent inhibition of P-glycoprotein expression. J Pharmacol Exp Ther 286: 419-428.

Al-Shawi MK, Senior AE (1993) Characterization of the adenosine triphosphatase activity of Chinese hamster Pglycoprotein. J Biol Chem 268: 4197-4206.

Al-Shawi MK, Urbatsch IL, Senior AE (1994) Covalent inhibitors of P-glycoprotein ATPase activity. J Biol Chem 269: 8986-8992.

Ambudkar SV, Lelong IH, Zhang J, Cardarelli CO, Gottesman MM, Pastan I (1992) Partial purification and reconstitution of the human multidrug-resistance pump: characterization of the drug-stimulatable ATP hydrolysis. Proc Natl Acad Sci USA 89: 8472-8476.

Ambudkar SV, Dey S, Hrycyna CA, Ramachandra M, Pastan I, Gottesman MM (1999) Biochemical, cellular, and pharmacological aspects of the multidrug transporter. Annu Rev Pharmacol Toxicol 39: 361-398.

Antonini I, Cola D, Polucci P, Bontemps-Gracz M, Borowski E, Martelli S (1995) Synthesis of (dialkylamino)alkyldisubstituted pyrimido[5,6,1-de]acridines, a novel group of anticancer agents active on a multidrug resistant cell line. J Med Chem 38: 3282-3286.

Antonini I, Polucci P, Cola D, Bontemps-Gracz M, Pescalli N, Menta E, Martelli S (1996) Pyrimido[4,5,6$\mathrm{kl}$ ]acridines, a new class of potential anticancer agents. Synthesis and biological evaluation. Anticancer Drug Des 11: 339-349.

Antonini I, Polucci P, Kelland LR, Menta E, Pescalli N, Martelli S (1999a) 2,3-Dihydro-1H,7H-pyrimido[5,6,1de]acridine-1,3,7-trione derivatives, a class of cytotoxic agents active on multidrug-resistant cell lines: synthesis, biological evaluation, and structure-activity relationships. J Med Chem 42: 2535-2541. 
Antonini I, Polucci P, Martelli S (1999b) Pyrimido[4,5,6$k l$ ]acridines. Synthesis, in vitro cytotoxicity and structure-activity relationships. Anticancer Drug Des 14: 451-459.

Antonini I, Polucci P, Magnano A, Martelli S (2001) Synthesis, antitumor cytotoxicity, and DNA-binding of novel N-5,2-di(omega-aminoalkyl)-2,6-dihydropyrazolo[3,4,5kl]acridine-5-carboxamides. J Med Chem 44: 3329-3333.

Antonini I, Polucci P, Magnano A, Gatto B, Palumbo M, Menta E, Pescalli N, Martelli S (2002) 2,6Di(omega-aminoalkyl)-2,5,6,7-tetrahydropyrazolo[3,4,5$m n$ ]pyrimido[5,6,1-de]acridine-5,7-diones: novel, potent, cytotoxic, and DNA-binding agents. J Med Chem 45: 696-702.

Astriab-Fisher A, Sergueev DS, Fisher M, Shaw BR, Juliano RL (2000) Antisense inhibition of P-glycoprotein expression using peptide-oligonucleotide conjugates. Biochem Pharmacol 60: 83-90.

Astriab-Fisher A, Ye D, Sergueev DS, Fisher MH, Shaw BR, Juliano RL (2002) Evaluating the specificity of antisense oligonucleotide conjugates. A DNA array analysis. I Biol Chem 277: 22980-22984.

Astriab-Fisher A, Fisher MH, Juliano R, Herdewijn P (2004) Increased uptake of antisense oligonucleotides by delivery as double stranded complexes. Biochem Pharmacol 68: 403-407.

Avendano C, Menendez JC (2002) Inhibitors of multidrug resistance to antitumor agents (MDR). Curr Med Chem 9: 159-193.

Azzaria M, Schurr E, Gros P (1989) Discrete mutations introduced in the predicted nucleotide-binding sites of the $m d r 1$ gene abolish its ability to confer multidrug resistance. Mol Cell Biol 9: 5289-5297.

Bartsevich VV, Juliano RL (2000) Regulation of the MDR1 gene by transcriptional repressors selected using peptide combinatorial libraries. Mol Pharmacol 58: 1-10.

Bates S, Kang M, Meadows B, Bakke S, Choyke P, Merino M, Goldspiel B, Chico I, Smith T, Chen C, Robey R, Bergan R, Figg WD, Fojo T (2001) A Phase I study of infusional vinblastine in combination with the $\mathrm{P}$ glycoprotein antagonist PSC 833 (valspodar). Cancer 92: 1577-1590.

Bergman AM, Munch-Petersen B, Jensen PB, Sehested M, Veerman G, Voorn DA, Smid K, Pinedo HM, Peters GJ (2001) Collateral sensitivity to gemcitabine $\left(2^{\prime}, 2^{\prime}\right.$ difluorodeoxycytidine) and cytosine arabinoside of daunorubicin- and VM-26-resistant variants of human small cell lung cancer cell lines. Biochem Pharmacol 61: 1401-1408.

Blagosklonny MV (1999) Drug-resistance enables selective killing of resistant leukemia cells: exploiting of drug resistance instead of reversal. Leukemia 13: 2031-2035.

Blagosklonny MV (2001) Treatment with inhibitors of caspases, that are substrates of drug transporters, selectively permits chemotherapy-induced apoptosis in multidrug-resistant cells but protects normal cells. Leukemia 15: 936-941.

Blagosklonny MV (2003) Targeting cancer cells by exploiting their resistance. Trends Mol Med 9: 307-312.

Boer R, Dichtl M, Borchers C, Ulrich WR, Marecek JF, Prestwich GD, Glossmann H, Striessnig J (1996) Reversible labeling of a chemosensitizer binding domain of P-glycoprotein with a novel 1,4-dihydropyridine drug transport inhibitor. Biochemistry 35: 1387-1396.

Boerner SA, Tourne ME, Kaufmann SH, Bible KC (2001) Effect of P-glycoprotein on flavopiridol sensitivity. $\mathrm{Br}$ Cancer 84: 1391-1396.

Bontemps-Gracz M, Milewski S, Borowski E (1991) The influence of L-norvalyl-N3-4-methoxyfumaroyl-L-2,3diaminopropanoic acid, an antifungal agent, on mam- malian cells in tissue culture. Acta Biochim Polon 38: 229-239.

Bontemps-Gracz MM, Kupiec A, Antonini I, Borowski E (2002) The ability to overcome multidrug resistance of tumor cell lines by novel acridine cytostatics with condensed heterocyclic rings. Acta Biochim Polon 49: 87-92.

Borst P, Evers R, Kool M, Wijnholds J (2000) A family of drug transporters: the multidrug resistance-associated proteins. I Natl Cancer Inst 92: 1295-1302.

Castro AF, Horton JK, Vanoye CG, Altenberg GA (1999) Mechanism of inhibition of P-glycoprotein-mediated drug transport by protein kinase $\mathrm{C}$ blockers. Biochem Pharmacol 58: 1723-1733.

Chen CJ, Chin JE, Ueda K, Clark DP, Pastan I, Gottesman MM, Roninson IB (1986) Internal duplication and homology with bacterial transport proteins in the mdr1 (P-glycoprotein) gene from multidrug-resistant human cells. Cell 47: 381-389.

Choi CH, Kim JH, Kim SH (2004) Reversal of P-glycopro-


and SAR. Biochem Biophys Res Commun 320: 672-679.

Chou TC, Zhang XG, Harris CR, Kuduk SD, Balog A, Savin KA, Bertino JR, Danishefsky SJ (1998) Desoxyepothilone $\mathrm{B}$ is curative against human tumor xenografts that are refractory to paclitaxel. Proc Natl Acad Sci USA 95: 15798-15802.

Cole SP, Bhardwaj G, Gerlach JH, Mackie JE, Grant CE, Almquist KC, Stewart AJ, Kurz EU, Duncan AM, Deeley RG (1992) Overexpression of a transporter gene in a multidrug-resistant human lung cancer cell line. Science 258: 1650-1654.

Conseil G, Baubichon-Cortay H, Dayan G, Jault JM, Barron D, Di Pietro A (1998) Flavonoids: a class of modulators with bifunctional interactions at vicinal ATP- and steroid-binding sites on mouse P-glycoprotein. Proc Natl Acad Sci USA 95: 9831-9836.

Conseil G, Perez-Victoria JM, Jault JM, Gamarro F, Goffeau A, Hofmann J, Di Pietro A (2001) Protein kinase $\mathrm{C}$ effectors bind to multidrug $\mathrm{ABC}$ transporters and inhibit their activity. Biochemistry 40: 2564-2571.

Crooke ST (1992) Therapeutic applications of oligonucleotides. Annu Rev Pharmacol Toxicol 32: 329-376.

Cucco C, Calabretta B (1996) In vitro and in vivo reversal of multidrug resistance in a human leukemia-resistant cell line by mdr1 antisense oligodeoxynucleotides. Cancer Res 56: 4332-4337.

Dalton WS, Scheper RJ (1999) Lung resistance-related protein: determining its role in multidrug resistance. J Natl Cancer Inst 91: 1604-1605.

Dantzig AH, Law KL, Cao J, Starling JJ (2001) Reversal of multidrug resistance by the P-glycoprotein modulator, LY335979, from the bench to the clinic. Curr Med Chem 8: 39-50.

Dantzig AH, de Alwis DP, Burgess M (2003) Considerations in the design and development of transport inhibitors as adjuncts to drug therapy. Adv Drug Deliv Rev 55: 133-150.

Dean M, Hamon Y, Chimini G (2001a) The human ATPbinding cassette $(\mathrm{ABC})$ transporter superfamily. J Lipid Res 42: 1007-1017.

Dean M, Rzhetsky A, Allikmets R (2001b) The human ATP-binding cassette (ABC) transporter superfamily. Genome Res 11: 1156-1166.

Dey S, Ramachandra M, Pastan I, Gottesman MM, Ambudkar SV (1997) Evidence for two nonidentical druginteraction sites in the human P-glycoprotein. Proc Natl Acad Sci USA 94: 10594-10599.

D'Incalci M (1998) Some hope from marine natural products. Ann Oncol 9: 937-938. 
Doyle LA, Yang W, Abruzzo LV, Krogmann T, Gao Y, Rishi AK, Ross DD (1998) A multidrug resistance transporter from human MCF-7 breast cancer cells. Proc Natl Acad Sci USA 95: 15665-15670.

Dzieduszycka M, Martelli S, Arciemiuk M, BontempsGracz MM, Kupiec A, Borowski E (2002) Effect of modification of 6-[(aminoalkyl)amino]-7H-benzo[e]-perimidin-7-ones on their cytotoxic activity toward sensitive and multidrug resistant tumor cell lines. Synthesis and biological evaluation. Bioorg Med Chem 10: 1025-1035.

Dzieduszycka M, Bontemps-Gracz MM, Stefanska B, Martelli S, Piwkowska A, Arciemiuk M, Borowski E (2005) Synthesis of 7-oxo-7H-naphto[1,2,3-de]quinoline derivatives as potential anticancer agents active on multidrug resistant cell lines. Bioorg Med Chem in press.

Efferth T, Lathan B, Volm M (1991) Selective growth-inhibition of multidrug-resistant $\mathrm{CHO}$-cells by the monoclonal antibody 265/F4. Br J Cancer 64: 87-89.

Efferth T, Volm M (1992) Antibody-directed therapy of multidrug-resistant tumor cells. Med Oncol Tumor Pharmacother 9: 11-19.

Efferth T, Volm M (1993) Modulation of P-glycoproteinmediated multidrug resistance by monoclonal antibodies, immunotoxins or antisense oligodeoxynucleotides in kidney carcinoma and normal kidney cells. Oncology 50: 303-308.

Efferth T, Futscher BW, Osieka R (2001) 5-Azacytidine modulates the response of sensitive and multidrugresistant K562 leukemic cells to cytostatic drugs. Blood Cells Mol Dis 27: 637-648.

Elbashir SM, Harborth J, Lendeckel W, Yalcin A, Weber K, Tuschl T (2001) Duplexes of 21-nucleotide RNAs mediate RNA interference in cultured mammalian cells. Nature 411: 494-498.

Endicott JA, Ling V (1989) The biochemistry of P-glycoprotein-mediated multidrug resistance. Anпu Rev Biochem 58: $137-171$.

Fardel O, Lecureur V, Guillouzo A (1996) The P-glycoprotein multidrug transporter. Gen Pharmacol 27: 12831291.

Ferry DR, Malkhandi PJ, Russell MA, Kerr DJ (1995) Allosteric regulation of $[3 \mathrm{H}]$ vinblastine binding to P-glycoprotein of MCF-7 ADR cells by dexniguldipine. Biochem Pharmacol 49: 1851-1861.

Ferte J (2000) Analysis of the tangled relationships between P-glycoprotein-mediated multidrug resistance and the lipid phase of the cell membrane. Eur J Biochem 267: 277-294.

Fire A, Xu S, Montgomery MK, Kostas SA, Driver SE, Mello CC (1998) Potent and specific genetic interference by double-stranded RNA in Caenorhabditis elegans. Nature 391: 806-811.

Fischer V, Rodriguez-Gascon A, Heitz F, Tynes R, Hauck C, Cohen D, Vickers AE (1998) The multidrug resistance modulator valspodar (PSC 833) is metabolized by human cytochrome P450 3A. Implications for drugdrug interactions and pharmacological activity of the main metabolite. Drug Metab Dispos 26: 802-811.

FitzGerald DJ, Willingham MC, Cardarelli CO, Hamada H, Tsuruo T, Gottesman MM, Pastan I (1987) A monoclonal antibody - Pseudomonas toxin conjugate that specifically kills multidrug-resistant cells. Proc Natl Acad Sci USA 84: 4288-4292.

Ford JM (1996) Experimental reversal of P-glycoproteinmediated multidrug resistance by pharmacological chemosensitisers. Eur J Cancer 32A: 991-1001.

Fulda S, Susin SA, Kroemer G, Debatin KM (1998) Molecular ordering of apoptosis induced by anticancer drugs in neuroblastoma cells. Cancer Res 58: 4453-4460.
Gao Z, Gao Z, Fields JZ, Boman BM (1998) Co-transfection of MDR1 and MRP antisense RNAs abolishes the drug resistance in multidrug-resistant human lung cancer cells. Anticancer Res 18: 3073-3076.

Garcia-Chaumont C, Seksek O, Grzybowska J, Borowski E, Bolard J (2000) Delivery systems for antisense oligonucleotides. Pharmacol Ther 87: 255-277.

Gardner SN (2002) Cell cycle phase-specific chemotherapy: computational methods for guiding treatment. Cell $\mathrm{Cy}$ cle 1: 369-374.

Gekeler V, Boer R, Ise W, Sanders KH, Schachtele C, Beck J (1995) The specific bisindolylmaleimide PKC-inhibitor GF 109203X efficiently modulates MRP-associated multiple drug resistance. Biochem Biophys Res Commun 206: 119-126.

Glazer RI (1998) The protein kinase ABC's of signal transduction as targets for drug development. Curr Pharm Des 4: $277-290$.

Goldman B (2003) Multidrug resistance: can new drugs help chemotherapy score against cancer? J Natl Cancer Inst 95: 255-257.

Gottesman MM, Pastan I (1993) Biochemistry of multidrug resistance mediated by the multidrug transporter. Annu Rev Biochem 62: 385-427.

Gottesman MM, Germann UA, Aksentijevich I, Sugimoto Y, Cardarelli CO, Pastan I (1994) Gene transfer of drug resistance genes. Implications for cancer therapy. Ann NY Acad Sci 716: 126-138.

Gottesman MM (2002) Mechanisms of cancer drug resistance. Annu Rev Med 53: 615-627.

Gottesman MM, Fojo T, Bates SE (2002) Multidrug resistance in cancer: role of ATP-dependent transporters. Nat Rev Cancer 2: 48-58.

Griffith OW, Meister A (1979) Potent and specific inhibition of glutathione synthesis by buthionine sulfoximine (S-n-butyl homocysteine sulfoximine). J Biol Chem 254: 7558-7560.

Gupta KP, Ward NE, Gravitt KR, Bergman PJ, O'Brian CA (1996) Partial reversal of multidrug resistance in human breast cancer cells by an N-myristoylated protein kinase C-alpha pseudosubstrate peptide. J Biol Chem 271: 2102-2111.

Hagenbuch B, Gao B, Meier PJ (2002) Transport of xenobiotics across the blood-brain barrier. News Physiol Sci 17: 231-234.

Haimeur A, Conseil G, Deeley RG, Cole SP (2004) The MRP-related and BCRP/ABCG2 multidrug resistance proteins: biology, substrate specificity and regulation. Curr Drug Metab 5: 21-53.

Hait WN, Choudhury S, Srimatkandada S, Murren JR (1993) Sensitivity of K562 human chronic myelogenous leukemia blast cells transfected with a human multidrug resistance cDNA to cytotoxic drugs and differentiating agents. J Clin Invest 91: 2207-2215.

Hamada H, Tsuruo T (1986) Functional role for the 170- to 180-kDa glycoprotein specific to drug-resistant tumor cells as revealed by monoclonal antibodies. Proc Natl Acad Sci USA 83: 7785-7789.

Hamada H, Miura K, Ariyoshi K, Heike Y, Sato S, Kameyama K, Kurosawa Y, Tsuruo T (1990) Mouse-human chimeric antibody against the multidrug transporter P-glycoprotein. Cancer Res 50: 3167-3171.

Hannon GJ (2002) RNA interference. Nature 418: 244-251.

Heike Y, Hamada H, Inamura N, Sone S, Ogura T, Tsuruo T (1990) Monoclonal anti-P-glycoprotein antibody-dependent killing of multidrug-resistant tumor cells by human mononuclear cells. Jpn J Cancer Res 81: 11551161.

Hooijberg JH, Broxterman HJ, Kool M, Assaraf YG, Peters GJ, Noordhuis P, Scheper RJ, Borst P, Pinedo HM, 
Jansen G (1999) Antifolate resistance mediated by the multidrug resistance proteins MRP1 and MRP2. Cancer Res 59: 2532-2535.

Huang Y, Ibrado AM, Reed JC, Bullock G, Ray S, Tang C, Bhalla K (1997) Co-expression of several molecular mechanisms of multidrug resistance and their significance for paclitaxel cytotoxicity in human AML HL-60 cells. Leukemia 11: 253-257.

Ichikawa M, Yoshimura A, Furukawa T, Sumizawa T, Nakazima Y, Akiyama S (1991) Glycosylation of P-glycoprotein in a multidrug-resistant $\mathrm{KB}$ cell line, and in the human tissues. Biochim Biophys Acta 1073: 309-315.

Idriss HT, Hannun YA, Boulpaep E, Basavappa S (2000) Regulation of volume-activated chloride channels by P-glycoprotein: phosphorylation has the final say! J Physiol 524: 629-636.

Izquierdo MA, Scheffer GL, Flens MJ, Schroeijers AB, van der Valk P, Scheper RJ (1996) Major vault protein LRPrelated multidrug resistance. Eur J Cancer 32A: 979984.

Jansen G, Barr H, Kathmann I, Bunni MA, Priest DG, Noordhuis P, Peters GJ, Assaraf YG (1999) Multiple mechanisms of resistance to polyglutamatable and lipophilic antifolates in mammalian cells: role of increased folylpolyglutamylation, expanded folate pools, and intralysosomal drug sequestration. Mol Pharmacol 55: 761-769.

Jedlitschky G, Leier I, Buchholz U, Barnouin K, Kurz G, Keppler D (1996) Transport of glutathione, glucuronate, and sulfate conjugates by the MRP gene-encoded conjugate export pump. Cancer Res 56: 988-994.

Jin J, Wang FP, Wei H, Liu G (2005) Reversal of multidrug resistance of cancer through inhibition of P-glycoprotein by 5-bromotetrandrine. Cancer Chemother Pharmacol 55: 179-188.

Jin S, Gorfajn B, Faircloth G, Scotto KW (2000) Ecteinascidin 743, a transcription-targeted chemotherapeutic that inhibits MDR1 activation. Proc Natl Acad Sci USA 97: 6775-6779.

Juliano RL, Ling V (1976) A surface glycoprotein modulating drug permeability in Chinese hamster ovary cell mutants. Biochim Biophys Acta 455: 152-162.

Kang H, Fisher MH, Xu D, Miyamoto YJ, Marchand A, Van Aerschot A, Herdewijn P, Juliano RL (2004) Inhibition of MDR1 gene expression by chimeric HNA antisense oligonucleotides. Nucleic Acids Res 32: 4411-4419.

Kawase M, Motohashi N (2003) New multidrug resistance reversal agents. Curr Drug Targets 4: 31-43.

Kellen JA (2003) The reversal of multidrug resistance: an update. J Exp Ther Oncol 3: 5-13.

Kim KH (2001) 3D-QSAR analysis of 2,4,5- and 2,3,4,5-substituted imidazoles as potent and nontoxic modulators of P-glycoprotein mediated MDR. Bioorg Med Chem 9: 1517-1523.

Kitada S, Zapata JM, Andreeff M, Reed JC (2000) Protein kinase inhibitors flavopiridol and 7-hydroxy-staurosporine down-regulate antiapoptosis proteins in B-cell chronic lymphocytic leukemia. Blood 96: 393-397.

Kitazono M, Okumura H, Ikeda R, Sumizawa T, Furukawa T, Nagayama S, Seto K, Aikou T, Akiyama S (2001) Reversal of LRP-associated drug resistance in colon carcinoma SW-620 cells. Int J Cancer 91: 126-131.

Kobayashi H, Takemura Y, Wang FS, Oka T, Ohnuma T (1999) Retrovirus-mediated transfer of anti-MDR1 hammerhead ribozymes into multidrug-resistant human leukemia cells: screening for effective target sites. Int J Cancer 81: 944-950.

Konig J, Nies AT, Cui Y, Leier I, Keppler D (1999) Conjugate export pumps of the multidrug resistance protein (MRP) family: localization, substrate specificity, and
MRP2-mediated drug resistance. Biochim Biophys Acta 1461: 377-394.

Krishna R, Mayer LD (2000) Multidrug resistance (MDR) in cancer. Mechanisms, reversal using modulators of MDR and the role of MDR modulators in influencing the pharmacokinetics of anticancer drugs. Eur J Pharm Sci 11: 265-283.

Krishna R, Mayer LD (2001) Modulation of P-glycoprotein (PGP) mediated multidrug resistance (MDR) using chemosensitizers: recent advances in the design of selective MDR modulators. Curr Med Chem Anti-Canc Agents 1: 163-174.

Kruh GD, Zeng H, Rea PA, Liu G, Chen ZS, Lee K, Belinsky MG (2001) MRP subfamily transporters and resistance to anticancer agents. J Bioenerg Biomembr 33: 493-501.

Lee $\mathrm{CH}$ (2004) Reversing agents for ATP-binding cassette (ABC) transporters: application in modulating multidrug resistance (MDR). Curr Med Chem Anti-Canc Agents 4: 43-52.

Lehne G (2000) P-glycoprotein as a drug target in the treatment of multidrug resistant cancer. Curr Drug Targets 1: 85-99.

Leung S, Bendayan R (1999) Role of P-glycoprotein in the renal transport of dideoxynucleoside analog drugs. Can J Physiol Pharmacol 77: 625-630.

Liscovitch M, Lavie Y (2002) Cancer multidrug resistance: a review of recent drug discovery research. IDrugs 5 : 349-355.

Litman T, Zeuthen T, Skovsgaard T, Stein WD (1997a) Structure-activity relationships of P-glycoprotein interacting drugs: kinetic characterization of their effects on ATPase activity. Biochim Biophys Acta 1361: 159-168.

Litman T, Zeuthen T, Skovsgaard T, Stein WD (1997b) Competitive, non-competitive and cooperative interactions between substrates of P-glycoprotein as measured by its ATPase activity. Biochim Biophys Acta 1361: 169-176.

Litman T, Brangi M, Hudson E, Fetsch P, Abati A, Ross DD, Miyake K, Resau JH, Bates SE (2000) The multidrug-resistant phenotype associated with overexpression of the new ABC half-transporter, MXR (ABCG2). J Cell Sci 113: 2011-2021.

Litman T, Druley TE, Stein WD, Bates SE (2001) From MDR to MXR: new understanding of multidrug resistance systems, their properties and clinical significance. Cell Mol Life Sci 58: 931-959.

Lofgren C, Hjortsberg L, Blennow M, Lotfi K, Paul C, Eriksson S, Albertioni F (2004) Mechanisms of cross-resistance between nucleoside analogues and vincristine or daunorubicin in leukemic cells. Biochem Biophys Res Commun 320: 825-832.

Loo TW, Clarke DM (2001) Defining the drug-binding site in the human multidrug resistance P-glycoprotein using a methanethiosulfonate analog of verapamil, MTSverapamil. J Biol Chem 276: 14972-14979.

Lu X, Gong S, Monks A, Zaharevitz D, Moscow JA (2002) Correlation of nucleoside and nucleobase transporter gene expression with antimetabolite drug cytotoxicity. J Exp Ther Oncol 2: 200-212.

Lum BL, Gosland MP (1995) MDR expression in normal tissues. Pharmacologic implications for the clinical use of P-glycoprotein inhibitors. Hematol Oncol Clin North Am 9: 319-336.

Ma L, Krishnamachary N, Center MS (1995) Phosphorylation of the multidrug resistance associated protein gene encoded protein P190. Biochemistry 34: 3338-3343.

Maki N, Hafkemeyer P, Dey S (2003) Allosteric modulation of human P-glycoprotein. Inhibition of transport 
by preventing substrate translocation and dissociation. J Biol Chem 278: 18132-18139.

Maliepaard M, van Gastelen MA, de Jong LA, Pluim D, van Waardenburg RC, Ruevekamp-Helmers MC, Floot BG, Schellens JH (1999) Overexpression of the BCRP/ MXR/ABCP gene in a topotecan-selected ovarian tumor cell line. Cancer Res 59: 4559-4563.

Marbeuf-Gueye C, Salerno M, Quidu P, Garnier-Suillerot A (2000) Inhibition of the P-glycoprotein- and multidrug resistance protein-mediated efflux of anthracyclines and calceinacetoxymethyl ester by PAK-104P. Eur J Pharmacol 391: 207-216.

Martin C, Berridge G, Higgins CF, Callaghan R (1997) The multi-drug resistance reversal agent SR33557 and modulation of vinca alkaloid binding to P-glycoprotein by an allosteric interaction. $\mathrm{Br} J$ Pharmacol 122: 765-771.

Martin C, Berridge G, Mistry P, Higgins C, Charlton P, Callaghan R (1999) The molecular interaction of the high affinity reversal agent XR9576 with P-glycoprotein. Br J Pharmacol 128: 403-411.

Martin C, Berridge G, Higgins CF, Mistry P, Charlton P, Callaghan R (2000) Communication between multiple drug binding sites on P-glycoprotein. Mol Pharmacol 58: 624-632.

Masuda Y, Kobayashi H, Holland JF, Ohnuma T (1998) Reversal of multidrug resistance by a liposome-MDR1 ribozyme complex. Cancer Chemother Pharmacol 42: 9-16.

Matsumoto Y, Miyake K, Kunishio K, Tamiya T, Nagao S (2004) Reduction of expression of the multidrug resistance protein (MRP) 1 in glioma cells by antisense phosphorothioate oligonucleotides. J Med Invest 51: 194-201.

Mechetner EB, Roninson IB (1992) Efficient inhibition of P-glycoprotein-mediated multidrug resistance with a monoclonal antibody. Proc Natl Acad Sci USA 89: 58245828.

Minderman H, O'Loughlin KL, Pendyala L, Baer MR (2004) VX-710 (biricodar) increases drug retention and enhances chemosensitivity in resistant cells overexpressing P-glycoprotein, multidrug resistance protein, and breast cancer resistance protein. Clin Cancer Res 10: 1826-1834.

Mizuno N, Niwa T, Yotsumoto Y, Sugiyama Y (2003) Impact of drug transporter studies on drug discovery and development. Pharmacol Rev 55: 425-461.

Muller C, Laurent G, Ling V (1995) P-glycoprotein stability is affected by serum deprivation and high cell density in multidrug-resistant cells. I Cell Physiol 163: 538-544.

Muller M, Meijer C, Zaman GJ, Borst P, Scheper RJ, Mulder NH, de Vries EG, Jansen PL (1994) Overexpression of the gene encoding the multidrug resistance-associated protein results in increased ATP-dependent glutathione S-conjugate transport. Proc Natl Acad Sci USA 91: 13033-13037.

Nagata J, Kijima H, Hatanaka H, Asai S, Miyachi H, Abe Y, Yamazaki H, Nakamura M, Watanabe N, Mine T, Kondo T, Scanlon KJ, Ueyama Y (2002) Reversal of drug resistance using hammerhead ribozymes against multidrug resistance-associated protein and multidrug resistance 1 gene. Int J Oncol 21: 1021-1026.

Naito M, Tsuge H, Kuroko C, Tomida A, Tsuruo T (1993a) Enhancement of reversing effect of cyclosporin A on vincristine resistance by anti-P-glycoprotein monoclonal antibody MRK-16. Jpn J Cancer Res 84: 489-492.

Naito M, Tsuge H, Kuroko C, Koyama T, Tomida A, Tatsuta T, Heike Y, Tsuruo T (1993b) Enhancement of cellular accumulation of cyclosporine by anti-P-glycoprotein monoclonal antibody MRK-16 and synergistic modulation of multidrug resistance. J Natl Cancer Inst 85: 311-316.
Ohishi Y, Oda Y, Uchiumi T, Kobayashi H, Hirakawa T, Miyamoto S, Kinukawa N, Nakano H, Kuwano M, Tsuneyoshi M (2002) ATP-binding cassette superfamily transporter gene expression in human primary ovarian carcinoma. Clin Cancer Res 8: 3767-3775.

Ojima I, Bounaud PY, Oderd CF (1998) Recent strategies for the treatment of multi-drug resistance in cancer cells. Exp Opin Ther Patents 8: 1587-1598.

Orlowski S, Garrigos M (1999) Multiple recognition of various amphiphilic molecules by the multidrug resistance P-glycoprotein: molecular mechanisms and pharmacological consequences coming from functional interactions between various drugs. Anticancer Res 19: 3109-3123.

Paddison PJ, Caudy AA, Hannon GJ (2002) Stable suppression of gene expression by RNAi in mammalian cells. Proc Natl Acad Sci USA 99: 1443-1448.

Pakunlu RI, Cook TJ, Minko T (2003) Simultaneous modulation of multidrug resistance and antiapoptotic cellular defense by MDR1 and BCL-2 targeted antisense oligonucleotides enhances the anticancer efficacy of doxorubicin. Pharm Res 20: 351-359.

Pastan I, Gottesman MM, Ueda K, Lovelace E, Rutherford AV, Willingham MC (1988) A retrovirus carrying an MDR1 cDNA confers multidrug resistance and polarized expression of P-glycoprotein in MDCK cells. Proc Natl Acad Sci USA 85: 4486-4490.

Perego P, De Cesare M, De Isabella P, Carenini N, Beggiolin G, Pezzoni G, Palumbo M, Tartaglia L, Pratesi G, Pisano C, Carminati P, Scheffer GL, Zunino F (2001) A novel 7-modified camptothecin analog overcomes breast cancer resistance protein-associated resistance in a mitoxantrone-selected colon carcinoma cell line. Cancer Res 61: 6034-6037.

Phylactou LA (2001) Ribozyme gene therapy. Methods Mol Biol 175: 521-529.

Pommerenke EW, Sinn H, Volm M (1995) Circumvention of doxorubicin-resistance in tumours by albumin-conjugated doxorubicin. Eur J Cancer 31A: 283-284.

Pommier Y, Sordet O, Antony S, Hayward RL, Kohn KW (2004) Apoptosis defects and chemotherapy resistance: molecular interaction maps and networks. Oncogene 23: 2934-2949.

Reed JC (2002) Apoptosis-based therapies. Nat Rev Drug Discov 1: 111-121.

Regev R, Assaraf YG, Eytan GD (1999) Membrane fluidization by ether, other anesthetics, and certain agents abolishes P-glycoprotein ATPase activity and modulates efflux from multidrug-resistant cells. Eur J Biochem 259: 18-24.

Renes J, de Vries EG, Nienhuis EF, Jansen PL, Muller M (1999) ATP- and glutathione-dependent transport of chemotherapeutic drugs by the multidrug resistance protein MRP1. Br J Pharmacol 126: 681-688.

Riordan JR, Ling V (1979) Purification of P-glycoprotein from plasma membrane vesicles of Chinese hamster ovary cell mutants with reduced colchicine permeability. J Biol Chem 254: 12701-12705.

Robert J, Jarry C (2003) Multidrug resistance reversal agents. J Med Chem 46: 4805-4817.

Robey RW, Medina-Perez WY, Nishiyama K, Lahusen T, Miyake K, Litman T, Senderowicz AM, Ross DD, Bates SE (2001) Overexpression of the ATP-binding cassette half-transporter, ABCG2 (Mxr/BCrp/ABCP1), in flavopiridol-resistant human breast cancer cells. Clin Cancer Res 7: 145-152.

Rowinsky EK, Smith L, Wang YM, Chaturvedi P, Villalona M, Campbell E, Aylesworth C, Eckhardt SG, Hammond L, Kraynak M, Drengler R, Stephenson J Jr, Harding MW, Von Hoff DD (1998) Phase I and phar- 
macokinetic study of paclitaxel in combination with biricodar, a novel agent that reverses multidrug resistance conferred by overexpression of both MDR1 and MRP. J Clin Oncol 16: 2964-2976.

Sandor V, Fojo T, Bates SE (1998) Future perspectives for the development of P-glycoprotein modulators, in preparation. Drug Resist Updat 1: 190-200.

Sato W, Yusa K, Naito M, Tsuruo T (1990) Staurosporine, a potent inhibitor of C-kinase, enhances drug accumulation in multidrug-resistant cells. Biochem Biophys Res Commun 173: 1252-1257.

Scala S, Akhmed N, Rao US, Paull K, Lan LB, Dickstein B, Lee JS, Elgemeie GH, Stein WD, Bates SE (1997) Pglycoprotein substrates and antagonists cluster into two distinct groups. Mol Pharmacol 51: 1024-1033.

Scheffer GL, Schroeijers AB, Izquierdo MA, Wiemer EA, Scheper RJ (2000) Lung resistance-related protein/major vault protein and vaults in multidrug-resistant cancer. Curr Opin Oncol 12: 550-556.

Schinkel AH, Kemp S, Dolle M, Rudenko G, Wagenaar E (1993) N-glycosylation and deletion mutants of the human MDR1 P-glycoprotein. J Biol Chem 268: 7474-7481.

Schinkel AH, Jonker JW (2003) Mammalian drug efflux transporters of the ATP binding cassette (ABC) family: an overview. Adv Drug Deliv Rev 55: 3-29.

Scotto KW, Johnson RA (2001) Transcription of the multidrug resistance gene MDR1: a therapeutic target. Mol Interv 1: 117-125.

Secchiero P, Vaccarezza M, Gonelli A, Zauli G (2004) TNFrelated apoptosis-inducing ligand (TRAIL): a potential candidate for combined treatment of hematological malignancies. Curr Pharm Des 10: 3673-3681.

Seelig A (1998) A general pattern for substrate recognition by P-glycoprotein. Eur J Biochem 251: 252-261.

Seigneuret M, Garnier-Suillerot A (2003) A structural model for the open conformation of the mdr1 P-glycoprotein based on the MsbA crystal structure. J Biol Chem 278: 30115-30124.

Senior AE, Bhagat S (1998) P-glycoprotein shows strong catalytic cooperativity between the two nucleotide sites. Biochemistry 37: 831-836.

Senior AE, Gros P, Urbatsch IL (1998) Residues in P-glycoprotein catalytic sites that react with the inhibitor 7 chloro-4-nitrobenzo-2-oxa-1,3-diazole. Arch Biochem Biophys 357: 121-125.

Shah MA, Schwartz GK (2001) Cell cycle-mediated drug resistance: an emerging concept in cancer therapy. Clin Cancer Res 7: 2168-2181.

Sinn H, Schrenk HH, Friedrich EA, Schilling U, MaierBorst W (1990) Design of compounds having an enhanced tumour uptake, using serum albumin as a carrier. Part I. Int J Rad Appl Instrum B 17: 819-827.

Stam RW, van den Heuvel-Eibrink MM, den Boer ML, Ebus ME, Janka-Schaub GE, Allen JD, Pieters R (2004) Multidrug resistance genes in infant acute lymphoblastic leukemia: Ara-C is not a substrate for the breast cancer resistance protein. Leukemia 18: 78-83.

Stefanska B, Dzieduszycka M, Martelli S, Tarasiuk J, Bontemps-Gracz M, Borowski E (1993) 6[(aminoalkyl)amino]-substituted $7 H$-benzo[e]perimidin7-ones as novel antineoplastic agents. Synthesis and biological evaluation. J Med Chem 36: 38-41.

Stefanska B, Dzieduszycka M, Bontemps-Gracz MM, Borowski E, Martelli S, Supino R, Pratesi G, De Cesare M, Zunino F, Kusnierczyk H, Radzikowski C (1999) 8,11-Dihydroxy-6-[(aminoalkyl)amino]-7H-benzo[e]perimidin-7-ones with activity in multidrug-resistant cell lines: synthesis and antitumor evaluation. J Med Chem 42: 3494-3501.
Stefanska B, Arciemiuk M, Bontemps-Gracz MM, Dzieduszycka M, Kupiec A, Martelli S, Borowski E (2003) Synthesis and biological evaluation of 2,7-dihydro- $3 \mathrm{H}$ dibenzo[de,h]cinnoline-3,7-dione derivatives, a novel group of anticancer agents active on a multidrug resistant cell line. Bioorg Med Chem 11: 561-572.

Stefanska B, Bontemps-Gracz MM, Antonini I, Martelli S, Arciemiuk M, Piwkowska A, Rogacka D, Borowski E (2005) 2,7-Dihydro-3H-pyridazino[5,4,3-kl]acridin-3-one derivatives, novel type of cytotoxic agents active on multidrug-resistant cell lines. Synthesis and biological evaluation. Bioorg Med Chem 13: 1969-1975.

Stehle G, Sinn H, Wunder A, Schrenk HH, Stewart JC, Hartung G, Maier-Borst W, Heene DL (1997) Plasma protein (albumin) catabolism by the tumor itself-implications for tumor metabolism and the genesis of cachexia. Crit Rev Oncol Hematol 26: 77-100.

Stewart AJ, Canitrot Y, Baracchini E, Dean NM, Deeley RG, Cole SP (1996) Reduction of expression of the multidrug resistance protein (MRP) in human tumor cells by antisense phosphorothioate oligonucleotides. Biochem Pharmacol 51: 461-469.

Sui G, Soohoo C, Affar el B, Gay F, Shi Y, Forrester WC, Shi Y (2002) A DNA vector-based RNAi technology to suppress gene expression in mammalian cells. Proc Natl Acad Sci USA 99: 5515-5520.

Szabo D, Keyzer H, Kaiser HE, Molnar J (2000) Reversal of multidrug resistance of tumor cells. Anticancer Res 20: 4261-4274.

Takemura H, Urasaki Y, Yoshida A, Fukushima T, Ueda T (2001) Simultaneous treatment with 1-beta-D-arabinofuranosylcytosine and daunorubicin induces crossresistance to both drugs due to a combination-specific mechanism in HL60 cells. Cancer Res 61: 172-177.

Tan B, Piwnica-Worms D, Ratner L (2000) Multidrug resistance transporters and modulation. Curr Opin Oncol 12: $450-458$.

Tanaka H, Ohshima N, Ikenoya M, Komori K, Katoh F, Hidaka H (2003) HMN-176, an active metabolite of the synthetic antitumor agent $\mathrm{HMN}-214$, restores chemosensitivity to multidrug-resistant cells by targeting the transcription factor NF-Y. Cancer Res 63: 6942-6947.

Tarasiuk J, Frezard F, Garnier-Suillerot A, Gattegno L (1989) Anthracycline incorporation in human lymphocytes. Kinetics of uptake and nuclear concentration. Biochim Biophys Acta 1013: 109-117.

Tarasiuk J, Stefanska B, Plodzich I, Tkaczyk-Gobis K, Seksek O, Martelli S, Garnier-Suillerot A, Borowski E (2002) Anthrapyridones, a novel group of antitumour non-cross resistant anthraquinone analogues. Synthesis and molecular basis of the cytotoxic activity towards K562/DOX cells. Br J Pharmacol 135: 1513-1523.

Tarasiuk J, Majewska E, Seksek O, Rogacka D, Antonini I, Garnier-Suillerot A, Borowski E (2004) The role of structural factors in the kinetics of cellular uptake of pyrazoloacridines and pyrazolopyrimidoacridines: implications for overcoming multidrug resistance towards leukaemia K562/DOX cells. Biochem Pharmacol 68: 1815-1823.

Tatsuta T, Naito M, Oh-hara T, Sugawara I, Tsuruo T (1992) Functional involvement of P-glycoprotein in blood-brain barrier. J Biol Chem 267: 20383-20391.

Teodori E, Dei S, Scapecchi S, Gualtieri F (2002) The medicinal chemistry of multidrug resistance (MDR) reversing drugs. Farmaco 57: 385-415.

Thiebaut F, Tsuruo T, Hamada H, Gottesman MM, Pastan I, Willingham MC (1987) Cellular localization of the multidrug-resistance gene product P-glycoprotein in normal human tissues. Proc Natl Acad Sci USA 84: 7735-7738. 
Thomas H, Coley HM (2003) Overcoming multidrug resistance in cancer: an update on the clinical strategy of inhibiting P-glycoprotein. Cancer Control 10: 159-165.

Tkaczyk-Gobis K, Tarasiuk J, Seksek O, Stefanska B, Borowski E, Garnier-Suillerot A (2001) Transport of new non-cross-resistant antitumor compounds of the benzoperimidine family in multidrug resistant cells. Eur J Pharmacol 413: 131-141.

Toppmeyer D, Seidman AD, Pollak M, Russell C, Tkaczuk K, Verma S, Overmoyer B, Garg V, Ette E, Harding MW, Demetri GD (2002) Safety and efficacy of the multidrug resistance inhibitor Incel (biricodar; VX-710) in combination with paclitaxel for advanced breast cancer refractory to paclitaxel. Clin Cancer Res 8: 670-678.

Tsuruo T, Iida H, Tsukagoshi S, Sakurai Y (1981) Overcoming of vincristine resistance in P388 leukemia in vivo and in vitro through enhanced cytotoxicity of vincristine and vinblastine by verapamil. Cancer Res 41: 1967-1972.

Tsuruo T, Hamada H, Sato S, Heike Y (1989) Inhibition of multidrug-resistant human tumor growth in athymic mice by anti-P-glycoprotein monoclonal antibodies. Jpn I Cancer Res 80: 627-631.

Tsuruo T, Naito M, Tomida A, Fujita N, Mashima T, Sakamoto H, Haga N (2003) Molecular targeting therapy of cancer: drug resistance, apoptosis and survival signal Cancer Sci 94: 15-21.

Van Dijk J, Tsuruo T, Segal DM, Bolhuis RL, Colognola R, van de Griend RJ, Fleuren GJ, Warnaar SO (1989) Bispecific antibodies reactive with the multidrug-resistance-related glycoprotein and CD3 induce lysis of multidrug-resistant tumor cells. Int J Cancer 44: 738743.

Vanhoefer U, Yin MB, Harstrick A, Seeber S, Rustum YM (1997) Carbamoylation of glutathione reductase by $\mathrm{N}, \mathrm{N}$-bis(2-chloroethyl)- $\mathrm{N}$-nitrosourea associated with inhibition of multidrug resistance protein (MRP) function. Biochem Pharmacol 53: 801-809.

Vanhuyse M, Kluza J, Tardy C, Otero G, Cuevas C, Bailly C, Lansiaux A (2005) Lamellarin D: a novel pro-apoptotic agent from marine origin insensitive to P-glycoprotein-mediated drug efflux. Cancer Lett 221: 165-175.

van Zuylen L, Nooter K, Sparreboom A, Verweij J (2000) Development of multidrug-resistance convertors: sense or nonsense? Invest New Drugs 18: 205-220.

Volm M (1998) Multidrug resistance and its reversal. Anticancer Res 18: 2905-2917.

Walder RY, Walder JA (1988) Role of RNase H in hybridarrested translation by antisense oligonucleotides. Proc Natl Acad Sci USA 85: 5011-5015.
Wang FS, Kobayashi H, Liang KW, Holland JF, Ohnuma $\mathrm{T}$ (1999) Retrovirus-mediated transfer of anti-MDR1 ribozymes fully restores chemosensitivity of P-glycoprotein-expressing human lymphoma cells. Hum Gene Ther 10: 1185-1195.

Wang H, Chen XP, Qiu FZ (2003) Overcoming multi-drug resistance by anti-MDR1 ribozyme. World J Gastroenterol 9: 1444-1449.

Watanabe T, Naito M, Kokubu N, Tsuruo T (1997) Regression of established tumors expressing P-glycoprotein by combinations of adriamycin, cyclosporin derivatives, and MRK-16 antibodies. J Natl Cancer Inst 89: 512-518.

Wielinga PR, Heijn M, Broxterman HJ, Lankelma J (1997) P-glycoprotein-independent decrease in drug accumulation by phorbol ester treatment of tumor cells. Biochem Pharmacol 54: 791-799.

Wiese M, Pajeva IK (2001) Structure-activity relationships of multidrug resistance reversers. Curr Med Chem 8: 685-713.

Wu H, Hait WN, Yang JM (2003) Small interfering RNAinduced suppression of MDR1 (P-glycoprotein) restores sensitivity to multidrug-resistant cancer cells. Cancer Res 63: 1515-1519.

Xu D, Ye D, Fisher M, Juliano RL (2002) Selective inhibition of P-glycoprotein expression in multidrug-resistant tumor cells by a designed transcriptional regulator. J Pharmacol Exp Ther 302: 963-971.

Yabuuchi H, Shimizu H, Takayanagi S, Ishikawa T (2001) Multiple splicing variants of two new human ATPbinding cassette transporters, $\mathrm{ABCC} 11$ and $\mathrm{ABCC} 12$. Biochem Biophys Res Commun 288: 933-939.

Yang HH, Ma MH, Vescio RA, Berenson JR (2003) Overcoming drug resistance in multiple myeloma: the emergence of therapeutic approaches to induce apoptosis. $J$ Clin Oncol 21: 4239-4247.

Yang JM, Vassil AD, Hait WN (2001) Activation of phospholipase $C$ induces the expression of the multidrug resistance (MDR1) gene through the Raf-MAPK pathway. Mol Pharmacol 60: 674-680.

Zamora JM, Pearce HL, Beck WT (1988) Physical-chemical properties shared by compounds that modulate multidrug resistance in human leukemic cells. Mol Pharmacol 33: 454-462.

Zeng H, Lin ZP, Sartorelli AC (2004) Resistance to purine and pyrimidine nucleoside and nucleobase analogs by the human MDR1 transfected murine leukemia cell line L1210/VMDRC.06. Biochem Pharmacol 68: 911-921. 